\title{
Roles of the NF-кB Pathway in Lymphocyte Development and Function
}

\author{
Steve Gerondakis ${ }^{1}$ and Ulrich Siebenlist ${ }^{2}$ \\ ${ }^{1}$ The Burnet Institute, 85 Commercial Rd, Prahran, Victoria 3004, Australia \\ ${ }^{2}$ Laboratory of Immunoregulation, National Institutes of Allergy and Infectious Diseases, \\ National Institutes of Health, Bethesda, Maryland 20892 \\ Correspondence: gerondakis@burnet.edu.au, usiebenlist@niaid.nih.gov
}

\begin{abstract}
This article focuses on the functions of NF- $\mathrm{B}$ that vitally impact lymphocytes and thus adaptive immunity. NF-кB has long been known to be essential for many of the responses of mature lymphocytes to invading pathogens. In addition, NF-кB has important functions in shaping the immune system so it is able to generate adaptive responses to pathogens. In both contexts, NF-кB executes critical cell-autonomous functions within lymphocytes as well as within supportive cells, such as antigen-presenting cells or epithelial cells. It is these aspects of NF-кB's physiologic impact that we address in this article.
\end{abstract}

\section{CELL-AUTONOMOUS ROLES OF NF- $\mathrm{B}$ IN LYMPHOCYTE DEVELOPMENT}

NF-кB makes numerous cell-autonomous contributions to the development of mature $\mathrm{T}$ and B lymphocytes. Given the importance of $\mathrm{NF}-\kappa \mathrm{B}$ in adaptive immune responses mediated by mature lymphocytes, it seems prudent for developing lymphocytes to have adopted a strategy in which their maturation hinges on a properly functioning NF- $\mathrm{\kappa B}$ system. As discussed later, the primary, though not exclusive, contribution of NF- $\kappa \mathrm{B}$ to lymphocyte development is to assure cell survival. These antiapoptotic functions of NF- $\kappa$ B remain crucial for the health of lymphocytes even after they mature. Unfortunately, these functions also aid tumorigenesis when NF- $к \mathrm{~B}$ is dysregulated (Vallabhapurapu and Karin 2009). Most of the insights about the role of NF- $\mathrm{B}$ in development of lymphocytes have come from analyses of genetically manipulated mice in which $\mathrm{NF}-\kappa \mathrm{B}$ components are missing or in which NF- $\mathrm{KB}$ activation has been compromised or is constitutively induced. B and T lymphocytes will be discussed in parallel to highlight similarities at related stages of their development. Figures 1 and 2 summarize some of the findings described later.

\section{Early Lymphocyte Progenitors}

Despite a clear role for the NF- $\kappa \mathrm{B}$ homolog Dorsal in early Drosophila development (Hong et al. 2008), in mammalian development no such role for NF- $\kappa \mathrm{B}$ has emerged, including development of early lymphocyte precursors. NF- $\mathrm{B}$ can, however, play a protective role in precursors to

Editors: Louis M. Staudt and Michael Karin

Additional Perspectives on NF-кB available at www.cshperspectives.org

Copyright (C) 2010 Cold Spring Harbor Laboratory Press; all rights reserved; doi: 10.1101/cshperspect.a000182

Cite this article as Cold Spring Harb Perspect Biol 2010;2:a000182 
S. Gerondakis and U. Siebenlist

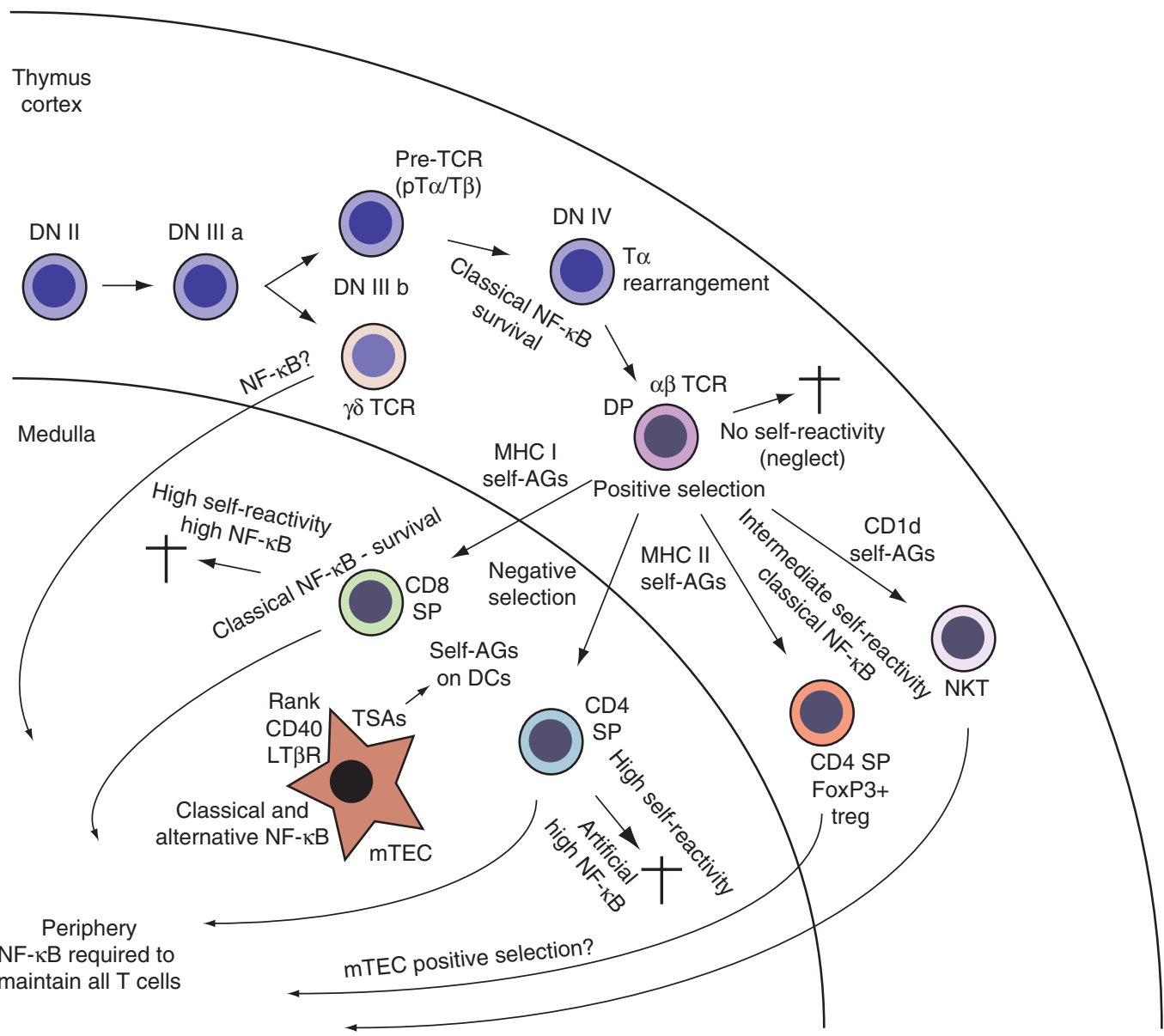

Figure 1. NF-кB in thymic T-cell development. Shown is a schematic and simplified representation of thymic T-cell development, highlighting stages at which NF- $\kappa \mathrm{B}$ contributes in a cell-autonomous fashion. Also highlighted is the requirement of NF-кB for generation of medullary thymic epithelial cells (mTECs). $\gamma \delta \mathrm{T}$ cells and $\mathrm{T} \beta$-expressing thymocytes can be distinguished at the (CD4, CD8) double negative (DN) stage III b. The pre-TCR $(\mathrm{pT} \alpha / \mathrm{T} \beta)$ drives development of thymocytes into DN IV cells, which in turn give rise to double positive (DP) cells ( $\alpha \beta$ TCR). Positive selection of DP thymocytes to become CD4 or CD8 singlepositive (SP) thymocytes is driven by weak recognition of self-AGs presented on cortical thymic epithelial cells in the context of MHC class II or class I, respectively. T-regulatory cells (Tregs, FoxP3+) and NKT cells may develop from DP thymocytes by recognition of self-AGs with intermediate strength (lipids presented on CD1d in the case of NKT cells). Failure to recognize self-AGs leads to elimination of thymocytes (death by neglect); strong recognition of self-AGs also leads to elimination (negative selection). Negative selection begins in the cortex but may occur predominantly in the medulla, where self-AGs are presented on dendritic cells (DCs) and on mTECs. mTECs produce tissue-specific (self)-AGs (TSAs) and can cross-prime DCs with these antigens. See text for further details.

protect them from $\mathrm{TNF} \alpha$-induced apoptosis. Artificially high levels of TNF $\alpha$ arise during adoptive transfers of hematopoietic stem cells into lethally irradiated hosts, so when donor cells were compromised in their ability to activate $\mathrm{NF}-\kappa \mathrm{B}$, reconstitution of lymphocytes failed
(Grossmann et al. 2000; Senftleben et al. 2001b; Claudio et al. 2006; Gerondakis et al. 2006; Igarashi et al. 2006). It is possible that a minimum of NF- $\kappa \mathrm{B}$ activity may yet be necessary even during normal development (normal levels of TNF $\alpha$ ). Female mice heterozygous for 


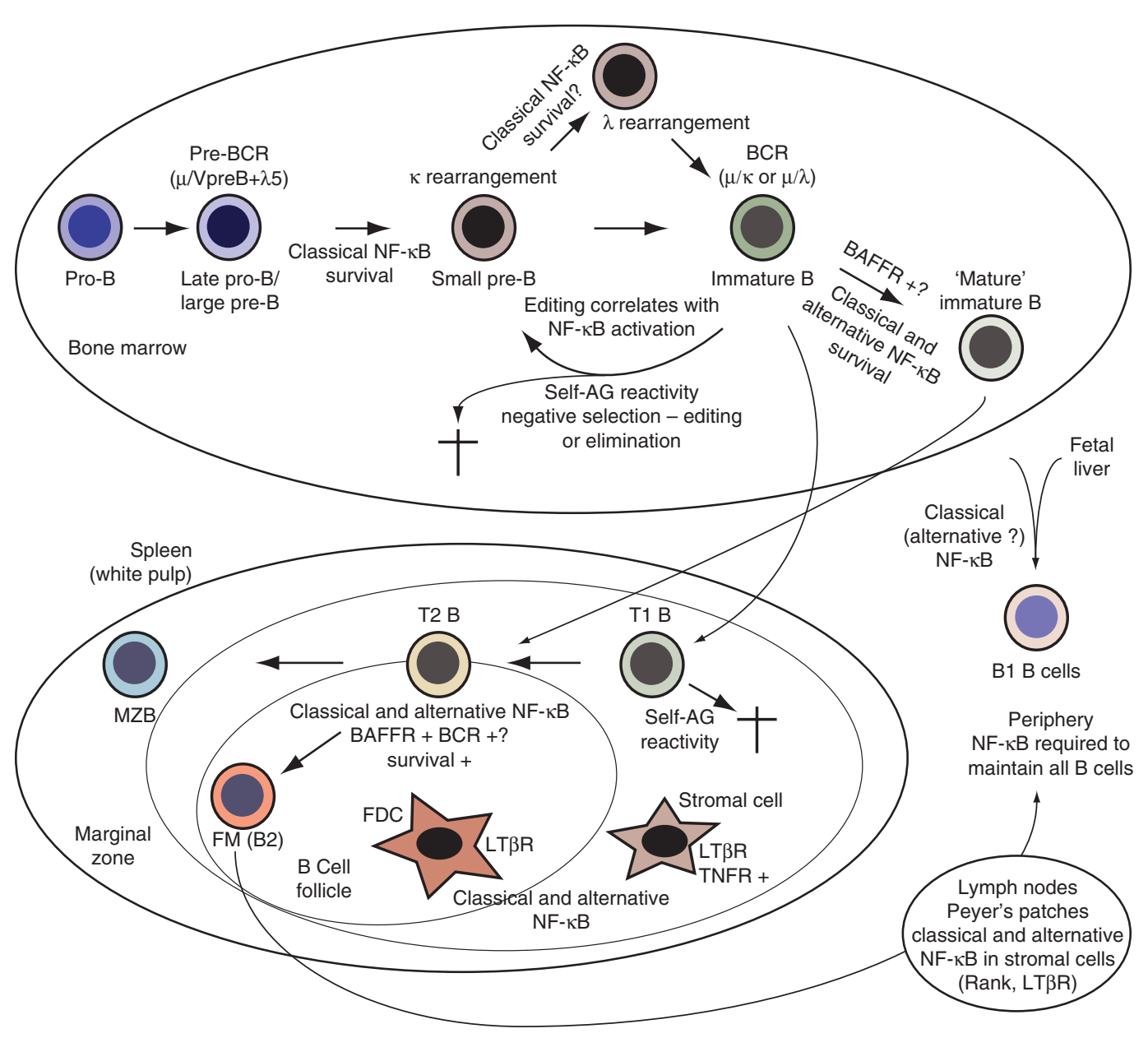

Figure 2. NF- $\kappa$ B in B cell development. A schematic and simplified representation of bone marrow and splenic B-cell development, highlighting stages at which NF- $\mathrm{B}$ contributes in a cell-autonomous fashion to formation of marginal zone (MZ B) and follicular mature (FM) B cells; the latter are also known as B2 B cells and enter the peripheral circulation. Also highlighted is the requirement for NF-кB in B1 B-cell development, a peripherally self-renewing population with precursors in fetal liver and possibly bone marrow. Also highlighted is the importance of NF- $\mathrm{BB}$ in stromal cells/follicular dendritic cells (FDCs) in forming a proper splenic architecture (B-cell follicles, marginal zone) and in forming Peyer's patches and lymph nodes. B-cell development commences in the bone marrow, where the pre-BCR on large pre- $\mathrm{B}$ cells (a.k.a. late pro-B) drives development into small (late) pre-B cells, which in turn give rise to immature B cells (first to express a full BCR [IgM]). Self-antigen (AG)-reactive immature B cells edit their receptors by further light chain gene rearrangements or they are eliminated (negative selection). Surviving immature and "more mature" immature B cells (T2-like) then migrate to the spleen (white pulp), where they progress through the transitional 1 (T1) and T2 stages to become FM (located in B cell follicles) and MZB cells (located in marginal zones). Early transitional-staged cells continue to be subject to negative selection. Generation of FMs and MZBs from early transitional stages is driven by signals from the BCR, BAFFR, and other receptors ("+") to assure survival, but also to regulate cell differentiation ("+") in part via NF- $\kappa$ B. (Additional minor pathways and populations have been postulated, but are not shown here.) See text for further details. 
loss of X-chromosome-encoded NEMO only generated NEMO sufficient, but not NEMO-deficient lymphocytes, even though random lyonization should have generated equal numbers (Makris et al. 2000; Schmidt-Supprian et al. 2000). NEMO (IKK $\gamma$ ) is an essential component of the classical pathway for NF- $\kappa \mathrm{B}$ activation, and absolutely required for NF- $\mathrm{KB}$ activation by $\mathrm{TNF} \alpha$ (reviewed in Hayden and Ghosh 2008; Vallabhapurapu and Karin 2009). It remains to be shown, however, if NEMO-deficient lymphocyte precursors were indeed eliminated by "normal" levels TNF $\alpha$

Pre-antigen Receptor Expressing Large Pre-B Cells and Double Negative (DN) Thymocytes

The appearance of pre-TCRs on DN thymocytes (stage III) and pre-BCRs on developing bone marrow large pre-B cells provides important, ligand-independent signals for expansion and progression to the DN stage IV/DP stage and to small pre-B cells, respectively ( $\mathrm{T}$ - and B-cell development reviewed in Bommhardt et al. 2004; Hardy et al. 2007; Allman and Pillai 2008; Northrup and Allman 2008; Taghon and Rothenberg 2008). These cells contain significant levels of nuclear NF- $\mathrm{\kappa B}$ activity, presumably because of activation by the pre-antigen receptors (Voll et al. 2000; Jimi et al. 2005; Derudder et al. 2009). Failure to assemble a preTCR receptor ( $\mathrm{pT} \alpha$ paired with rearranged TRC $\beta$ ) or pre-BCR (VpreB and $\gamma 5$ surrogate light chains paired with rearranged $\mu$ heavy chain) eliminates these cells.

I $\mathrm{B}$ super-repressor-mediated interference with NF- $\kappa \mathrm{B}$ activation in pre-TCR expressing thymocytes led to their apoptosis (Voll et al. 2000), because of interference with NF-кBmediated induction of the antiapoptotic Bcl-2 family member A1 (Mandal et al. 2005; Aifantis et al. 2006). Furthermore, exogenous expression of a constitutively active IKK $\beta$ allowed some DN thymocytes to progress to the double positive (DP) stage, even in the absence of a pre-TCR in RAG-deficient mice (Voll et al. 2000). Similarly, in pre-BCR ${ }^{+}$large pre-B cells, suppression of NF- $\kappa$ B by the I $\kappa$ B super-repressor also resulted in apoptosis, which could be overcome by ectopic expression of Bcl-xL, another NF-кBinduced antiapoptotic member of the Bcl-2 family (Feng et al. 2004a; Jimi et al. 2005). At a minimum, these data imply a survival role for NF- $\kappa \mathrm{B}$ in both pre-BCR and pre-TCR dependent development of $\mathrm{B}$ and $\mathrm{T}$ lymphocytes (this has previously been reviewed [Denk et al. 2000; Siebenlist et al. 2005; Claudio et al. 2006; Vallabhapurapu and Karin 2009]).

\section{Small (Late) Pre-B Cells}

Following cellular activation via pre-BCRs, cells no longer express the receptor and enter the small pre-B cell stage. On successful rearrangement of their light chains, they begin to express a full BCR (IgM) on their surface and are termed immature B cells (Hardy et al. 2007; Northrup and Allman 2008). Circumstantial evidence has implicated NF- $\mathrm{KB}$ in demethylation of the $\kappa$ light chain (LC) locus, an obligate step during $\kappa$ gene rearrangement (Goldmit et al. 2005). However, loss of the intronic $\kappa$ enhancer containing the first known $\kappa \mathrm{B}$ binding site had no effect on this process (Inlay et al. 2004; Sen 2004), and a recent report implies no or only a minor role for NF- $\kappa \mathrm{B}$ in $\kappa$ locus demethylation (Derudder et al. 2009). mb1 promoter-driven Cre-induced conditional ablation of NEMO (eliminating the classical pathway) or of both IKK kinase subunits (IKK1 and IKK2; eliminating classical and alternative $\mathrm{NF}-\kappa \mathrm{B}$ pathways) at this stage of development did not significantly reduce $\kappa$ LC expressing (immature) B cells. Surprisingly though, $\lambda$ LC expressing immature B cells were reduced. Rearrangement of the $\lambda$ locus is temporally delayed relative to that of $\kappa$, so it is possible that these $B$ cells require NF- $\mathrm{B}$ activity to allow them to survive longer. In support, the antiapoptotic protein kinase Pim2 was down-modulated in NEMO/IKK deficient small B cells and ectopic expression of a Bcl-2 transgene resurrected $\lambda \mathrm{LC}$ rearrangements.

It is not known what signals activate NF- $\kappa \mathrm{B}$ at this stage. CD40, Bcl-10, MyD88, and ATM kinase were not required (Derudder et al. 2009); the latter was thought to be potentially involved 
in NF- $\mathrm{KB}$ activation and developmental progression in response to double-stranded DNA breaks associated with DNA rearrangements (Bredemeyer et al. 2008). Because Bcl-10 was not required, one might conclude that antigenreceptor signaling is not involved, but it is possible that this receptor can activate NF- $\kappa B$ by an unconventional pathway (see further discussion later). Loss of TRAF6 did reduce the number of $\lambda$-expressing B cells (Derudder et al. 2009), but many signaling receptors in addition to the antigen receptor avail themselves of this adaptor.

Immature (Bone Marrow) B Cells and Negative Selection

Autoreactive immature (bone marrow) B cells are subject to negative selection, but rather than undergo immediate apoptosis, a portion of these cells reactivate the RAG recombinase to further rearrange (edit) their light chain in hope of generating a nonautoreactive BCR (Nemazee 2006). Strong engagement of selfantigens was reported to down-regulate BCR cell surface expression and de-differentiate immature B cells back to the small pre-B cell stage (Schram et al. 2008). Contrary to an earlier report that concluded a critical role for NF- $\kappa \mathrm{B}$ in RAG regulation during negative selection (Verkoczy et al. 2005), a recent report instead attached an at best only minor role to NF-кB: receptor editing for $\kappa$ light chains and RAG expression levels were not significantly affected in $\mathrm{B}$ cells conditionally ablated for NEMO or for both IKK1 and IKK2, although as noted previously, $\lambda$ light chain rearrangement was affected (Derudder et al. 2009). On the other hand, another recent study found a strong correlation between elevated NF-кB activity (induced by autoreactive BCRs) and various indicators of receptor editing, suggesting a causal relationship, even though these authors also failed to find a link between NF- $\mathrm{KB}$ and RAG expression (Cadera et al. 2009). These divergent conclusions might yet be reconciled if for example some NF- $\mathrm{KB}$ could be activated by BCRs via a NEMO/IKK independent mechanism.

NF- $\kappa B$ may contribute to the survival of immature cells during the negative selection/ editing phase and thereafter. Initial in vitro studies with immature B-like WEHI321 cells suggested as much; $\alpha$-IgM induced apopotis of these cells could be prevented if cells were also stimulated with $\alpha$-CD40, which led to sustained NF- $\mathrm{BB}$ activity, and in turn, higher c-myc levels (Schauer et al. 1998). CD40 activates both the classical and the alternative (nonclassical, noncanonical) pathways for NF- $\mathrm{\kappa B}$ (Mineva et al. 2007; Hayden and Ghosh 2008; Vallabhapurapu and Karin 2009). We recently documented a partial reduction in numbers of immature bone marrow $\mathrm{B}$ cells in mice lacking

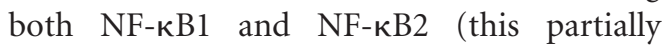
eliminates classically and alternatively activated complexes) (Claudio et al. 2009). This loss correlated with impaired survival of mutant immature B cells. Activation of the alternative pathway in wild-type immature B cells is likely to occur via BAFF receptor signaling (Claudio et al. 2009), which was also suggested by another study that implicated BAFF receptor signaling in the de novo generation of a small subset of "more mature" immature B cells in bone marrow (Lindsley et al. 2007). The previously cited report on conditional ablation of NEMO or of IKK1/IKK2 in B cells also showed a reduction in the more mature immature B cells (Derudder et al. 2009).

\section{DP and SP "Conventional" Thymocytes: Positive and Negative Selection}

After " $\beta$ " selection of pre- $\mathrm{TCR}^{+} \mathrm{DN}$ thymocytes (stage III), these cells rearrange their TCR $\alpha$ gene (DN stage IV) and become DP $\left(\mathrm{CD} 4^{+} \mathrm{CD} 8^{+}\right)$ $\mathrm{TCR} \alpha \beta^{+}$thymocytes (Bommhardt et al. 2004; Taghon and Rothenberg 2008). At this time, the thymocytes are subjected first to positive and then, in an overlapping fashion, to negative selection, while they physically move from the thymic cortex to the medulla (Boehm 2008). TCRs that fail to recognize self-antigens presented by MHCs are deleted (neglect), whereas weakly self-reactive TCRs are positively selected and strongly self-reactive TCRs are negatively selected (death by apoptosis). Surviving thymocytes become CD4 or CD8 single positive (SP) (depending on recognition of MHC class II or I, 
respectively), undergo further maturation, and eventually exit the thymus to enter the peripheral circulation as mature naïve $\mathrm{T}$ cells (Bommhardt et al. 2004; Taghon and Rothenberg 2008).

The role of NF-кB in selection remains somewhat controversial; NF- $\mathrm{KB}$ appears to have both positive and negative effects, probably because TCR signal strengths can be sensed within cells via the level of NF- $\mathrm{KB}$ activation; too much or too little activity may be selected against. Early studies with mice expressing IкB super-repressor transgenes have suggested a role for NF- $\mathrm{KB}$ in positive selection of CD8, and, to a lesser degree, of CD4 SP thymocytes, including studies with mouse models expressing TCR transgenes that weakly recognize selfpeptides presented on class I or class II MHCs, respectively (positive selection) (Boothby et al. 1997; Hettmann and Leiden 2000; Mora et al. 2001). On the other hand, NF-кB has also been implicated in promoting apoptosis of DP thymocytes mimicked by $\alpha$-CD3 treatment in vivo (Hettmann et al. 1999; Ren et al. 2002) and in mouse models with TCRs that strongly recognize self-peptides presented on class I or class II (negative selection) (Mora et al. 2001), although one study failed to see a role for NF- $\mathrm{KB}$ in class I negative selection (Hettmann and Leiden 2000).

In these studies, it is difficult to differentiate roles of NF- $\mathrm{KB}$ during the initial positive/negative selection from roles during the subsequent, SP stage, although a more recent study implicates NF- $\kappa \mathrm{B}$ in the latter stage, especially in CD8 SP thymocytes. Mice conditionally ablated in thymocytes for NEMO or that conditionally express a kinase deficient (potentially dominant negative-acting) form of IKK $\beta$ in thymocytes generated significantly fewer CD8 SP thymocytes, and had no peripheral T cells, including CD4 T cells (Schmidt-Supprian et al. 2003). However, straight loss of IKK $\beta$ was well tolerated, suggesting compensation by IKK $\alpha$. This study only informed on IKK/NF- $\mathrm{KB}$ in SP but not DP thymocytes, because the lck- or CD4-driven genetic changes only became fully penetrant after thymocytes had traversed the DP stage. Those SP thymocytes that remained in this NF-кB impaired model exhibited increased expression of apoptotic markers, consistent with an antiapoptotic role for NF-кB. This study was further able to conclude that NF- $\kappa B$ was continuously required in T cells even after they emerged from the thymus, i.e., the maintenance of the peripheral population depended on NF-кB. A very recent study has added further insight, strongly implicating NF- $\kappa \mathrm{B}$ in positive and negative selection of CD8 (DP and SP stage), but surprisingly, not of CD4 thymocytes. This study relied on mouse models with transgenes featuring positively or negatively selectable TCRs as well as an Iк $\mathrm{B} \alpha$ super-repressor or a constitutively active mutant IKK2 kinase (Jimi et al. 2008). IкB $\alpha$ super-repressor mediated inhibition of NF- $\mathrm{KB}$ eliminated cells expressing TCRs that weakly recognized MHC class I-presented self-peptides (CD8 positive selection), while also preventing the elimination of cells expressing TCRs that strongly recognized class I-presented self-peptides (CD8 negative selection). Confirming a role for strong NF- $\kappa \mathrm{B}$ activity in negative selection, high NF- $\mathrm{KB}$ activity induced by constitutively active IKK2 eliminated some cells during positive selection for $\mathrm{CD} 8$, presumably mimicking a strong TCR signal that pushed cells into a negative selection mode. Thus, the level of NF- $\mathrm{KB}$ activity appeared to reflect TCR signal strength during CD8 selection, thereby setting thresholds for positive and negative selection. A low level of NF- $\mathrm{B}$ activity during CD8 positive selection allowed cells to avoid death by neglect, whereas a high level was needed during CD8 negative selection to induce cell death. Interestingly, CD8 but not CD4 thymocytes expressed significant levels of NF- $\kappa$ B, which may explain why the IкB $\alpha$ super-repressor had little to no effect on CD4 selection processes. However, constitutively active IKK2 also eliminated cells during positive selection for CD4, presumably pushing these cells into a "pseudo"-negative selection mode. CD8 $\mathrm{T}$ cells may depend on a minimum of NF- $\mathrm{KB}$ for survival because they have very low levels of Bcl-2, whereas CD4 T cells express high levels of this antiapoptotic regulator, rendering them independent of NF- $\kappa B$ 's antiapoptotic functions. It is surprising that high levels of NF- $\mathrm{\kappa B}$ activity promoted cell death during negative selection, given the 
NF-kB and Lymphocytes

almost universal linkage of NF- $\kappa \mathrm{B}$ with survival functions; how this is accomplished remains an interesting, yet open question. It will also be of interest to determine how DP thymocytes differentially regulate for $N F-\kappa B$ depending on whether their TCRs recognize self-peptides in the context of class I or class II MHCs; this may involve other signals coming from antigen-presenting cells. The Iк $\mathrm{B} \alpha$ super-repressor transgene models cited previously do have one inherent shortcoming; NF- $\mathrm{BB}$ inhibition is likely to be only partial, with the degree of inhibition dependent on the level of expression of the transgene, which may vary between cells and models.

How NF- $\kappa \mathrm{B}$ is activated in thymocytes during positive and negative selection is not fully understood. If TCR signaling is responsible, then it must activate NF- $\mathrm{B}$ by an "unconventional" pathway, given obligate components of the "conventional" pathway (as defined in mature T cells) could be largely dispensed with for generation of more mature SP thymocytes / peripheral T cells. Regardless of this finding, the conventional pathway is likely to contribute to $\mathrm{NF}-\kappa \mathrm{B}$ activation during pre-TCR signaling (Sun et al. 2000; Lin and Wang 2004; Thome 2004; Felli et al. 2005; Jost et al. 2007). Obligate components of the conventional pathways include PKC $\theta$ and "CBM" complex components Carma1, Bcl-10, and Malt1 (PKC $\theta$ may have an NF- $\kappa \mathrm{B}$-independent role though [Morley et al.2008]). Interestingly, a recent study reports the existence of an unconventional signaling path for TCR-mediated activation of NF- $\kappa$ B in mature CD8, but not CD4 T cells (Kingeter and Schaefer 2008); if such a pathway was also functional during selection of CD8 thymocytes, it would be consistent with the role for NF- $\kappa \mathrm{B}$ in the development of these cells as discussed previously. Alternatively, NF-кB may also be activated by other signals, independent of the TCR. In either case, Tak1 is most likely involved; Tak 1 functions just upstream of the IKK complex in response to many NF- $\mathrm{KB}$ activating signals, and loss of this kinase reduced the number of SP thymocytes, and especially peripheral T cells, because of increased apoptosis (Liu et al. 2006; Sato et al. 2006; Wan et al. 2006).

\section{Nonconventional T Cells}

T-regulatory (Treg) cells recognize self-antigens, yet escape negative selection, possibly because they recognize self-antigens with intermediate strength (Caton et al. 2004; Lu and Rudensky 2009). Invariant natural killer $\mathrm{T}$ cells (iNKT; a.k.a. NKT) also recognize self-antigens (along with foreign ones), although in this case the antigens are lipids presented to developing NKT cells by CD1d on thymocytes (MacDonald and Mycko 2007; Burrows et al. 2009). $\gamma \delta \mathrm{T}$ cells are also thought to recognize certain selfantigens, but not in the context of MHC or CD1d (Thedrez et al. 2007; Xiong and Raulet 2007; Taghon and Rothenberg 2008). Autoantigen-mediated TCR signaling may thus promote the development of all of these cell types, and it may do so in an NF- $\kappa$ B dependent manner.

The conditional loss of IKK $\beta$ in thymocytes prevented the emergence of Treg and NKT cells (Schmidt-Supprian et al. 2003, 2004a); therefore, IKK $\alpha$ was unable to compensate, even though it did during development of conventional T cells. Furthermore, a compound deficiency of c-Rel and NF- $\mathrm{BB} 1$ abrogated Treg generation (Zheng et al. 2003), while loss of RelA or the presence of the I $\mathrm{B} \alpha$ super-repressor blocked NKT development (Sivakumar et al. 2003; Vallabhapurapu et al. 2008).

The commitment of early thymocytes to the Treg lineage (as determined by FoxP3 expression) was fully dependent on TCR-induced conventional signaling for activation of NF- $\mathrm{B}$ (PKC9, CBM, and Tak1 were all required) (Schmidt-Supprian et al. 2004a; Sato et al. 2006; Wan et al. 2006; Barnes et al. 2009; Medoff et al. 2009; Molinero et al. 2009). For NKT cells, PKC $\theta$ and the CBM adaptor complex were not absolutely required, although PKC $\theta$ contributed to thymic and Bcl-10 to peripheral NKT-cell numbers, respectively (Schmidt-Supprian et al. 2004a; Medoff et al. 2009). On the other hand, stimulation of thymocytes via NKT-specific V $\alpha 14 \mathrm{i}$ TCRs was reported to activate RelA/ NF- $\kappa$ B complexes and thereby induce expression of IL-15 receptor $\alpha$ and the common $\gamma$ chain $(\gamma c)$, which in turn allowed for IL-15 and IL-7 mediated expansion of NK1.1 ${ }^{-}$NKT 
precursors and maturation to $\mathrm{NK} 1.1^{+} \mathrm{NKT}$ cells (Vallabhapurapu et al. 2008). It is possible that TCRs on NKT activated NF- $\kappa$ B by a nonconventional pathway; alternatively, TCR independent signals might also have contributed to NF- $\kappa \mathrm{B}$ activation.

Like NKTs, $\gamma \delta$ T cells have innate and adaptive functions; they are able to rapidly produce $\gamma$ IFN or IL-17 in response to a variety of stimuli (Taghon and Rothenberg 2008; Jensen and Chien 2009). Relatively little is known about their development, but recently their differentiation into $\gamma$ IFN producing cells was reported to be imprinted early in developing $\gamma \delta$ thymocytes, correlating with expression of TNF receptor members CD27 and LT $\beta$ Rs (Ribot et al. 2009). The latter is thought to be engaged by LT $\alpha \beta$-expressing DP thymocytes. The presence of CD27 and LT $\beta$ R suggests roles for the classical and alternative pathways in generating $\gamma$ IFN producing $\gamma \delta \mathrm{T}$ cells, although this remains to be shown.

Transitional and Follicular Mature B Cells and Nonconventional Marginal Zone and B1 B Cells

Immature B cells eventually leave the bone marrow and migrate to the spleen to complete their maturation process. There they undergo several phenotypic and functional changes to become follicular mature (FM) B cells (a.k.a. B2 B cells), which recirculate in the periphery, and marginal zone B cells (MZB), which are largely sessile, although they may shuttle between the marginal zone and follicles to transport and present antigens (Thomas et al. 2006; Hardy et al. 2007; Allman and Pillai 2008). In this way, MZBs contribute to T-dependent antigen responses, but MZBs can also rapidly respond to pathogens in a T-independent, innate-like fashion. MZBs are a first line of defense to blood-borne pathogens, as splenic marginal zones filter these pathogens out of the blood stream (Lopes-Carvalho et al. 2005). B1 B cells represent a distinct lineage from B2 B cells; they populate the peritoneal and pleural cavities and are thought to originate from fetal liver precursors that self-renew in the periphery, although some precursors may reside in the bone marrow (Allman and Pillai 2008). Like MZBs, B1 B cells participate in rapid T-independent innate-like antibody production and appear to recognize some selfantigens.

Newly arrived immature B cells in the spleen are referred to as transitional-1 B cells (T1); these cells continue to be subject to negative selection pressures, as antigen-receptor stimulation induces apoptosis. At some time during the T2 stage, B cells instead begin to respond positively to antigen-receptor stimulation, whereupon they become FM and MZB cells. The mechanisms underlying the divergence of FM and MZB remain poorly understood. In some studies, an additional third transitional $\mathrm{B}$ cell stage has been distinguished phenotypically, but this population may also include anergic B cells (Thomas et al. 2006; Hardy et al. 2007; Allman and Pillai 2008).

NF- $\mathrm{BB}$ is absolutely essential for the survival of developing $\mathrm{B}$ cells in the spleen. Compound deficiencies in NF- $\mathrm{BB} 1 / \mathrm{NF}-\kappa \mathrm{B} 2$ and c-Rel/RelA profoundly arrested B-cell development at or shortly after the transition from T1 to $\mathrm{T} 2$, and resulted in a near-complete absence of FM and MZB cells (Franzoso et al. 1997b; Grossmann et al. 2000; Claudio et al. 2002, 2006; Gerondakis et al. 2006); a milder reduction of FM B cells occurred with compound deficiencies of NF-кB1/c-Rel (Pohl et al. 2002; Gerondakis et al. 2006) and NF-кB2/Bcl-3 or NIK/Bcl-3 (U.S., unpubl. results). These results suggest involvement of the classical and alternative pathways. Loss of alternative pathway components only (NF- $\mathrm{KB} 2$, NIK, or IKK $\alpha$ ) resulted in partial reductions of more mature B cells (Franzoso et al. 1998; Yamada et al. 2000; Kaisho et al. 2001; Senftleben et al. 2001a; Siebenlist et al. 2005; Claudio et al. 2006). Bcl-3 is an atypical member of the ІкВ family and its involvement was unexpected. Bcl-3 may be induced by classical NF- $\mathrm{\kappa B}$ activation and it is likely to modulate gene transcription via association with DNA-binding p50 homodimers in the nucleus, although biologic targets during B-cell development are unknown (Palmer and Chen 2008; Yamamoto and Takeda 2008). The severe block in B-cell development in the compound 
deficient NF- $\kappa \mathrm{B}$ models cited previously was because of loss of survival; early transitional $\mathrm{B}$ cells (T1) from these mutant mice expressed lower levels of the antiapoptotic proteins Bcl-2 and $\mathrm{A} 1$, and exhibited increased spontaneous apoptosis in culture. Ectopic expression of $\mathrm{Bcl}-2$ allowed the transitional B cells to survive and progress further; however, these cells did not fully mature phenotypically or functionally, remaining unable to produce antibodies. Therefore, NF-кB is critical not only for survival of transitional B cells, but also for the complete development of functions that accompanies differentiation.

During the transitional phases, BAFF (a.k.a. BLyS, TNFSF13B) induces the alternative pathway in B cells via the BAFF receptor (BAFFR, a.k.a. BR3, TNFRSF13C) (Claudio et al. 2002; Stadanlick and Cancro 2008; Mackay and Schneider 2009; Rauch et al. 2009). Because loss of BAFFR blocks B-cell maturation more profoundly than loss of the alternative pathway, BAFFR must contribute additional signals for cell survival. Although the alternative pathway does promote $\mathrm{Bcl}-2$ expression, and, indirectly, the retention in the cytoplasm of otherwise apoptotic nuclear PKC反 (Sasaki et al. 2006), BAFFR also activates AKT, independently of NF-кB (Otipoby et al. 2008). Interestingly, a mutant form of the alternative pathway component $\mathrm{p} 100 / \mathrm{NF}-\mathrm{\kappa B} 2$ that cannot be processed to p52 caused a substantial block in T1 to T2/M maturation (Tucker et al. 2007); the mutant p100 eliminates the alternative NF- $\mathrm{KB}$ activation, but, in addition, it also inhibits p65 (RelA) complexes, which are normally activated by the classical pathway (Kanno et al. 1994).

Although the alternative pathway contributes to B-cell maturation, the classical pathway is absolutely required. This conclusion was already apparent from the results with c-Rel, RelA compound deficiency (see previous discussion) and was confirmed with NEMO $(\mathrm{IKK} \gamma)$ deficient B cells. Conditional loss of NEMO in B cells with CD19- or mb1-Cre caused significant arrest at or near the T1 to T2 transition with a near complete absence of mature B cells; similarly induced conditional expression of a kinase deficient form of IKK $\beta$ (see previous discussion) caused a milder block, whereas outright (conditional) loss of IKK $\beta$ caused no discernable block at the T1 to T2 transition (Pasparakis et al. 2002; Sasaki et al. 2007; Derudder et al. 2009). However, all three (B-cell specific) genetic changes nearly eliminated or at least severely reduced numbers of mature recirculating $B$ cells. The most straightforward interpretation of these results is that during the transitional phases, IKK $\alpha$ may partially compensate for the outright loss of IKK $\beta$ to activate the classical pathway (a similar situation was seen in conventional thymocyte development discussed previously). On the other hand, once B cells have matured, they absolutely require IKK2-mediated classical activation for long-term survival. The most severe block at the $\mathrm{T} 1$ to $\mathrm{T} 2$ transition occurred in mice conditionally ablated with mb1-Cre for both IKK1 and IKK2; the block was more complete than that observed in the absence of NEMO (Derudder et al. 2009). This suggests that IKK1 also contributes in a NEMO-independent fashion, presumably via the alternative pathway. Of note, a constitutively active form of IKK2 was able to completely overcome the absence of BAFFR, indicating that the classical pathway is both necessary and sufficient to allow full maturation of $B$ cells in the absence of BAFFR/alternative activation (Sasaki et al. 2006). However, because the alternative pathway was required for optimal generation of B cells under normal conditions, it must be inferred that the classical pathway is not normally sufficiently activated.

It has been suggested that weak tonic BCR signaling activates the classical pathway, which in turn is required to set up the alternative pathway by inducing expression of BAFFR and NF-кB2 via c-Rel (Stadanlick et al. 2008; Castro et al. 2009). However, BCR-independent signals must also be considered, because loss of CBM complex components (Carma1, Bcl-10, or Malt1) only mildly reduced FM B-cell numbers (CBM is part of the conventional signaling path from the BCR to NF- $\kappa B$; see TCR signaling discussed previously) (Thome 2004; Ferch et al. 2007). This situation is somewhat reminiscent of what was noted for development of naïve $\mathrm{T}$ cells, and again raises the possibility that BCRs 
and TCRs may activate NF- $\mathrm{BB}$ in developing lymphocytes by an unconventional pathway. Whatever the pathway or signal, TAK1 was reported to be required for B-cell maturation (Schuman et al. 2009), although an earlier report appears to be at odds with this finding (Sato et al. 2005), while TRAF6 was reported to be at least partially required (Kobayashi et al. 2009). However, these proteins can be part of many NF- $\mathrm{KB}$ signaling pathways, so their involvement does not inform on the nature of the signal.

The generation of MZB cells is particularly sensitive to perturbations in NF- $\mathrm{KB}$ activity. Single deficiency in NF-кB1, NF-кB2 or RelB and to a lesser extent c-Rel or RelA in B cells already reduced numbers of MZBs (Caamano et al. 1998; Franzoso et al. 1998; Cariappa et al. 2000; Weih et al. 2001; Guo et al. 2007), although there may be an unexplained rebound with advancing age in NF- $\mathrm{kB} 1$ knockouts (Ferguson and Corley 2005). Furthermore, loss of IKK2 essentially eliminated these cells (Pasparakis et al. 2002). NF-кB1 reportedly synergizes with Notch2 receptor signaling during generation of MZBs, but mechanisms remain to be elucidated (Moran et al. 2007; Allman and Pillai 2008). The exquisite dependence of MZBs on NF- $\kappa \mathrm{B}$ activity is also highlighted by mouse models in which the numbers of these cells were augmented. CYLD is deubiquitinase for K63-linked ubiquitin chains, which downmodulates the classical pathway by targeting proteins such as NEMO and RIP (Courtois 2008). The loss of CYLD in B cells led to a marked increase in constitutive NF- $\mathrm{\kappa B}$ activity and a significant rise in MZBs (Jin et al. 2007). Overactivation of the alternative pathway also led to a selective increase of MZBs, as is the case in mice with a BAFF transgene (Mackay and Schneider 2009) or in mice deficient in the IкB-like part of p100/NF-кB2, leaving p52 to form complexes with RelB and enter nuclei (Guo et al. 2007). Finally, loss of Bcl-3 unexpectedly increased MZB cell numbers; this implicates Bcl-3 as a gatekeeper during MZB formation (U.S., unpubl. observations). As discussed previously, Bcl-3 is an unusual ІкB family member; how it normally suppresses
MZB development remains to be determined, although it might do so by dampening NF-кB target gene expression.

MZB cells have been suggested to be selected by expression of weakly self-reactive BCRs that avoid negative selection but are possibly strong enough to activate some NF- $\kappa \mathrm{B}$ to aid in their survival and/or expansion (Allman and Pillai 2008). Such a scenario would be consistent with the fact that components of the conventional BCR signaling path to NF- $\kappa B$ were required for MZB development (e.g., Carma1, Malt1, Bcl-10, TRAF6, and Tak1) (Thome 2004; Pappu and Lin 2006; Kobayashi et al. 2009; Schuman et al. 2009).

Formation of B1 B cells is highly dependent on the function of the conventional BCR signaling pathway to NF- $\kappa \mathrm{B}$ and on NF- $\kappa \mathrm{B}$ activity, possibly because these cells are thought to be selected for fairly strong recognition of selfantigens (Allman and Pillai 2008). Loss of component parts of this pathway (Thome 2004; Sato et al. 2005; Kobayashi et al. 2009; Schuman et al. 2009) or interference with NF- $\mathrm{KB}$ activity blocked development of B1 B cells; for example, deficiency in NF-кB1 already reduced their numbers, whereas a deficiency in both c-Rel and NF-кB1 nearly eliminated them (FM cell numbers were only mildly affected) (Pohl et al. 2002; Gerondakis et al. 2006). c-Rel is particularly important for cell-cycle entry and proliferation in response to BCR stimulation (Gilmore et al. 2004), suggesting the possibility that B1 B cells may expand in response to BCR signaling induced by self-antigens. As expected, $\mathrm{B} 1 \mathrm{~B}$ cells also failed to develop in the absence of IKK2 (Pasparakis et al. 2002). Interestingly, loss of NF- $\kappa \mathrm{B} 1$ and NF- $\kappa \mathrm{B} 2$ severely diminished B1 B-cell numbers (Claudio et al. 2002), implying a possible role for the alternative pathway of activation, even though BAFFR was not required (Mackay and Schneider 2009; Rauch et al. 2009).

\section{NF-кB IN THYMIC EPITHELIAL CELLS}

NF- $\kappa \mathrm{B}$ activity in epithelial cells is critical for central tolerance, i.e., tolerance of selfantigens enforced in the thymus via elimination 
(negative selection) of autoreactive TCRs (see previous discussion). Negative selection of conventional thymocytes with strongly autoreactive TCRs begins during interaction with self-antigen presented on cortical thymic epithelial cells (cTECs; also responsible for positive selection), but the bulk of negative selection is thought to take place in the medulla, where self-antigens are presented by thymic dendritic cells (DCs) and medullary thymic epithelial cells (mTECs) (Kyewski and Klein 2006; Boehm 2008; Nitta et al. 2008). mTECs promiscuously express many tissue specific self-antigens (TSAs), such as insulin and salivary protein 1 , driven in part via the AIRE regulator; mTECs also efficiently cross-prime thymic DCs with these selfantigens (Mathis and Benoist 2009). mTECs are likely required for accumulation of thymic DCs in the medulla (Tykocinski et al. 2008). Finally, mTECs may help promote Treg development, at least those with specificities to TSAs, although this remains to be shown (Zhang et al. 2007; Koble and Kyewski 2009).

Development/differentiation of mTECs is under control of NF- $\mathrm{BB}$. In the prenatal stage, generation of mTECs is induced by interaction with hematopoietic lymphoid tissue inducer cells (LTi) (Kim et al. 2009). These cells express ligands for RANK and LT $\beta$ receptors and thereby activate NF- $\kappa \mathrm{B}$ in mTEC progenitors via matching receptors (Akiyama et al. 2008). Thereafter, continued generation and maintenance of the mTEC network is controlled by positively selected DP thymocytes, which express ligands for RANK, LT $\beta$, and CD40 to stimulate mTECs (Akiyama et al. 2008; Hikosaka et al. 2008). Autoreactive thymocytes in particular have been suggested to promote the generation of mTECs (Irla et al. 2008). mTECs turn over rapidly, express self-antigens optimally on terminal differentiation, and crossprime thymic DCs, most likely in a process linked to their turnover (Yano et al. 2008; Koble and Kyewski 2009). The nuclear protein AIRE facilitates expression of a significant portion of the promiscuously produced TSAs and it may also have a role in terminal differentiation and antigen presentation (Yano et al. 2008; Koble and Kyewski 2009; Mathis and Benoist
2009). Expression of some TSAs is independent of AIRE and instead may be produced by a distinct subclass of mTECs, dependent on LT $\beta R$ signaling (Martins et al. 2008; Seach et al. 2008).

RANK, CD40, and LT $\beta$ R are TNF receptor family members that activate both classically and alternatively activated NF-кB complexes (Ghosh and Hayden 2008; Hayden and Ghosh 2008; Vallabhapurapu and Karin 2009). Consistent with a critical role for the alternative pathway, loss of NIK, IKK $\alpha$, RelB (Weih et al. 1995; Kajiura et al. 2004; Kinoshita et al. 2006), or compound loss of NF- $\mathrm{kB} 2$ and Bcl-3 abrogated the appearance of differentiated mTECs (Zhang et al. 2007). This in turn engendered multiorgan inflammation and early death, directly mediated by autoreactive $\mathrm{T}$ cells emerging from the thymus (Zhang et al. 2007) (U.S., unpubl. observations). Loss of NF-кB2 alone caused only mild impairment of mTECs, presumably because of $\mathrm{p} 50 /$ RelB complexes that remain active in the absence of $\mathrm{p} 100 / \mathrm{NF}-\kappa \mathrm{B} 2$, the primary inhibitor of RelB (Zhu et al. 2006; Zhang et al. 2007). As discussed previously, Bcl-3 is not part of the alternative pathway and is most likely induced by the classical pathway. It is not known how the combined loss of both NF- $\mathrm{KB} 2$ and $\mathrm{Bcl}-3$ leads to such a profound defect. Bcl-3 most likely functions by interaction with NF- $\kappa \mathrm{B} 1$; this is consistent with a complete block in mTEC development in mice lacking NF- $\mathrm{B} 1$ and NF-кB2 (Zhang et al. 2007).

The classical NF- $\kappa$ B pathway is also indispensable. TRAF6 knockout mutants failed to develop mTECs and exhibited multiorgan inflammation (Inoue et al. 2007; Akiyama et al. 2008). TRAF6 is engaged by numerous signals and functions just upstream of the IKK complex in the classical pathway (Ghosh and Hayden 2008; Hayden and Ghosh 2008; Vallabhapurapu and Karin 2009). RelB and NF-кB2 are likely critical targets of the classical pathway, because continuous production of these components of the alternative pathway would be required for long-term activation of this pathway (Inoue et al. 2007; Akiyama et al. 2008). Chemokines, such as CCR7 ligands, are important targets of $\mathrm{NF}-\kappa \mathrm{B}$ in epithelial cells that permit the 
attraction of positively selected DP thymocytes (Förster et al. 2008; Nitta et al. 2008). But how the alternative and/or classical pathways control the generation of mTECs themselves is an open question.

The alternative pathway and RelB may also have a specific role in nonhematopoietic cells required for thymic iNKT formation (Elewaut et al. 2003; Sivakumar et al. 2003; Franki et al. 2005), although recent reports suggest that LT $\beta R$ mediated activation of this pathway may be primarily required for thymic export/peripheral colonization of these cells and not their development (Franki et al. 2006; Vallabhapurapu et al. 2008).

\section{SECONDARY LYMPHOID ORGANS: NF-кB IN STROMAL CELLS}

The classical and alternative activation of $\mathrm{NF}-\kappa \mathrm{B}$ in stromal cells is instrumental in establishing secondary lymphoid organs and/or lymphoid organ architecture. The lymphoid organs provide the anatomical niches required for optimal initiation and expansion of adaptive immune responses (Drayton et al. 2006; Mueller and Ahmed 2008; Randall et al. 2008). A number of mouse mutants in which the alternative pathway was fully or partially blocked failed, to variable degrees, in forming splenic B-cell follicles, proper marginal zones, lymph nodes, Peyer's patches, and germinal centers. These mutants include those deficient in RelB or $\mathrm{NIK}$, or with compound deficiency in NF-кB2 and $\mathrm{Bcl}-3$, or harboring inactivating mutations of IKK $\alpha$ or NIK (Matsushima et al. 2001; Senftleben et al. 2001a; Weih et al. 2001; Paxian et al. 2002; Yilmaz et al. 2003; Weih and Caamano 2003; Zhang et al. 2007). Loss of NF-кB2 alone had milder defects, consistent with only partial abrogation of RelB complexes (see previous discussion) (Franzoso et al. 1998; Weih and Caamano 2003; Guo et al. 2007). Interestingly, loss of Bcl-3 also displayed some mild defects in lymphoid architecture (Franzoso et al. 1997b; Poljak et al. 1999).

The absence of splenic B-cell follicles in mice impaired in alternative NF- $\mathrm{KB}$ activation in the models cited previously correlated with a lack of follicular dendritic cell (FDC) networks (Weih and Caamano 2003; Zhang et al. 2007). FDCs present antigen-antibody immune complexes to facilitate clonal selection/differentiation of antigen-activated $\mathrm{B}$ cells in germinal center reactions that generate plasma cells and memory B cells (Allen and Cyster 2008; Mueller and Ahmed 2008; Batista and Harwood 2009). Apart from the ability of both FDCs and thymic mTECs to present antigens, these cells have many other parallels. They attract their lymphocyte partners by expressing chemoattractants-in the case of FDCs, CXCL13 (a.k.a. BLC) to attract B and organize them into follicles. These cells also require continuous stimulation by lymphocytes to maintain their differentiated network (Allen and Cyster 2008; Mueller and Ahmed 2008; Batista and Harwood 2009). B cells express LT $\alpha \beta$ (and Light) and signal FDCs via LT $\beta$ Rs to activate RelB complexes via the alternative pathway, in turn inducing expression of chemokines, e.g., CXCL13 (Suto et al. 2009). LT $\beta R$ signaling also activates RelA complexes, either by direct activation of the classical pathway or by liberating RelA complexes inhibited by p100 (Muller and Siebenlist 2003; Basak et al. 2007). Mice blocked in activation of the alternative pathway share many of the same defects apparent in mice deficient in LT $\beta$ R signaling (Matsushima et al. 2001; Hehlgans and Pfeffer 2005; Drayton et al. 2006; Ruddle and Akirav 2009). The alternative pathway is also required within stromal cells to form proper marginal zones. Impaired signaling via this pathway decreased the numbers of MZB cells, even if the pathway was intact within B cells (where it also plays a role; see previous discussion). RelB and the alternative pathway appear to control integrin-ligand interactions and chemokine expression required for MZB retention (Weih et al. 2001; Weih and Caamano 2003; Guo et al. 2007).

Activation of the alternative pathway via LT $\beta \mathrm{R}$ in stromal (mesenchymal organizer) cells is essential for lymph node and Peyer's patch organogenesis (Drayton et al. 2006; Elewaut and Ware 2007; Vondenhoff et al. 2007). Similar to the situation in prenatal mTEC development, hematopoietic LTi cells initiate the process in 
part via expression of ligands for LT $\beta R$ and RANK (Evans and Kim 2009); subsequently, B cells provide the necessary ligands (Elewaut and Ware 2007). Interestingly, only organogenesis of lymph nodes, but not of Peyer's patches, requires RANK activation on stromal cells, a potent activator of both the alternative and classical pathway for NF- $\mathrm{KB}$ (see previous discussion) (Yoshida et al. 2002).

In addition to RANK and LT $\beta$ R, the TNF receptor I may also play a role in lymphoid organogenesis and maintenance, although it only stimulates the classical pathway (Ruddle and Akirav 2009). The importance of the classical pathway is also underscored by the role of the adaptor protein TRAF6, which mediates classical activation by many receptors, including RANK, though not TNF receptor I (Ghosh and Hayden 2008; Hayden and Ghosh 2008; Vallabhapurapu and Karin 2009); TRAF6 was required within stromal cells for proper splenic architecture (e.g., B-cell follicles, marginal zones) as well as for lymph node and Peyer's patch organogenesis (Qin et al. 2007). Similar to the situation with mTECs, the classical pathway is likely required to induce expression of RelB and NF- $\mathrm{KB} 2$ to provide the components needed for continuous signaling via the alternative pathway (see previous discussion); in addition, the classical pathway may induce expression of Bcl-3. Little is known about how NF- $\kappa \mathrm{B}$ controls the development/differentiation of stromal cells, such as FDCs, but as in mTECs, NF- $\kappa$ B does induce expression of chemokines essential for cellular interactions and compartmentalization in secondary lymphoid organs (Vondenhoff et al. 2007; Mueller and Ahmed 2008; Randall et al. 2008; Evans and Kim 2009; Suto et al. 2009).

\section{NF- $\mathrm{B}$ AND B-CELL ACTIVATION}

Mature B-cell populations respond to two broad categories of antigen: so-called thymusindependent (TI) and thymus (T)-dependent antigens. Polyvalent antigens that typically possess multiple repeat determinants found on macromolecules such as polysaccharides can activate B cells without T-cell help. These
T-independent humoral responses, dominated by $\mathrm{CD} 5^{+}$and marginal zone B cells, typically involve the secretion of relatively low affinity IgM antibodies (McHeyzer-Williams 2003). Follicular B cells on the other hand, which serve as precursors of T-dependent B-cell responses to protein antigens are typically triggered by activated helper T cells through CD40 and receptors for cytokines such as IL-4 (McHeyzer-Williams and McHeyzer-Williams 2005). This leads to isotype switching and germinal center formation in secondary lymphoid organs, during which somatic hyper-mutation and antigen-driven selection produce long-lived affinity-matured plasma cells, plus memory $\mathrm{B}$ cells that can respond rapidly to antigen rechallenge ( $\mathrm{McHeyz}-$ er-Williams 2003; McHeyzer-Williams and McHeyzer-Williams 2005). A dichotomy between T-dependent and T-independent B-cell responses is unlikely to be as clear-cut in the context of a microbial infection, in which multivalent antigens are encountered in conjunction with protein antigens. Figure 3 outlines those stages during follicular B-cell activation and differentiation that involve NF- $\kappa \mathrm{B}$ signaling.

Mature $\mathrm{B}$ cells express different forms of NF- $\kappa$ B. In resting cells, NF- $\kappa \mathrm{B} 1 / \mathrm{c}-$ Rel heterodimers and NF- $\mathrm{B} 1$ homodimers predominate (Grumont and Gerondakis 1994), with RelA (NF-кB1/RelA, c-Rel/RelA) and NF-кB2 (NF$\kappa \mathrm{B} 2 /$ RelB, NF- $\kappa$ B2 homodimers) dimers also present, albeit at lower levels. Constitutive, lowgrade nuclear expression of NF- $\kappa \mathrm{B}$ factors downstream of both the classical and alternate pathway is a feature of nonactivated B cells that is thought to mainly serve a survival role (Gerondakis and Strasser 2003; Claudio et al. 2006). Low intensity, nonmitogenic BCR signals sustain the production of p100 NF- $\mathrm{B} 2$, which in turn serves to transmit survival signals through the BLyS receptor, BR3 (a.k.a. BAFFR) (Stadanlick et al. 2008).

Functional and developmental outcomes for B cells, including proliferation, differentiation, and survival that arise from specific types of activation signals, are reflected in the qualitative and quantitative nature of NF- $\mathrm{B}$ responses. $\mathrm{BCR}, \mathrm{CD} 40$, and TLR receptors all individually engage NF- $\mathrm{B}$ during $\mathrm{B}$-cell activation 
S. Gerondakis and U. Siebenlist

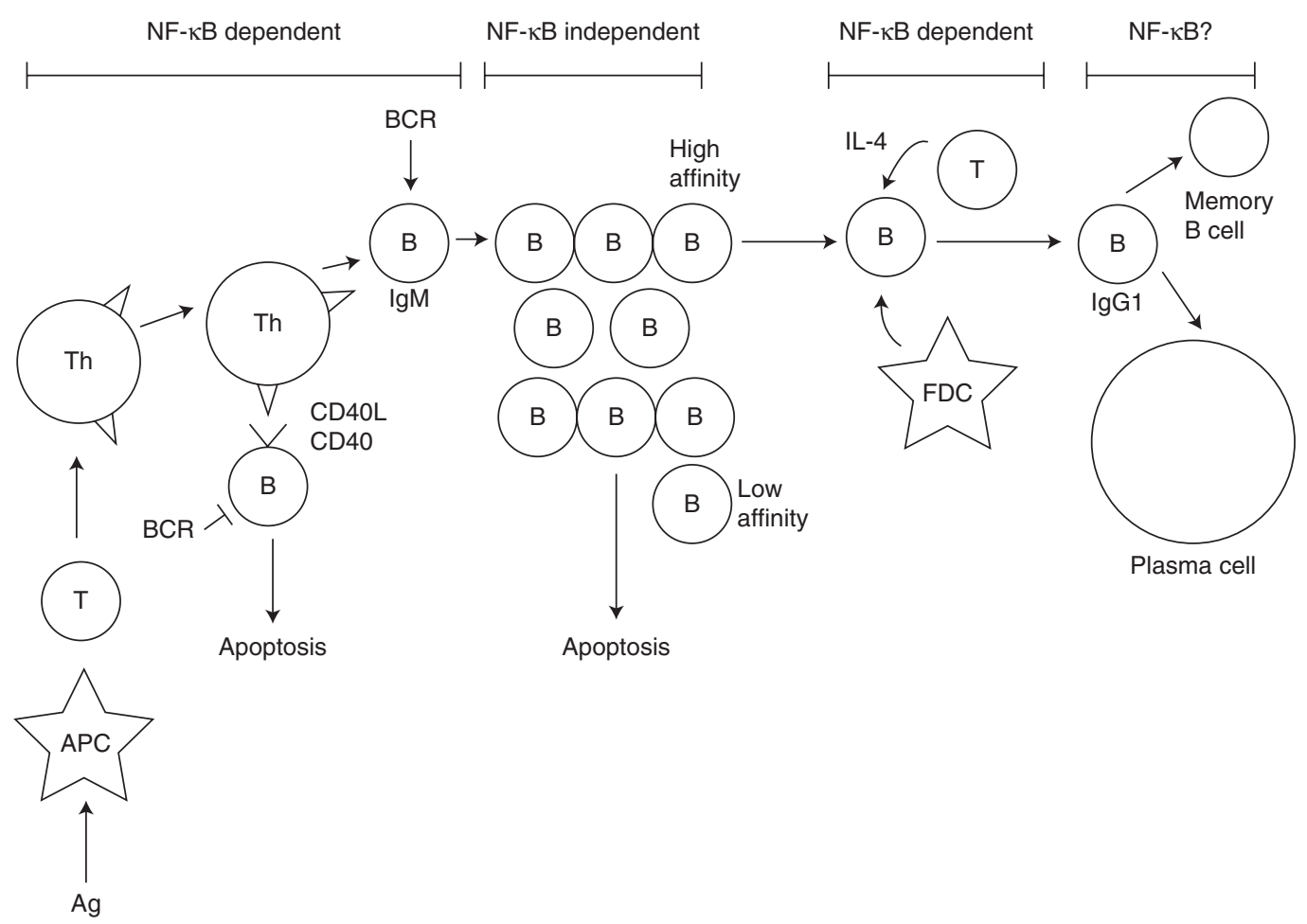

Figure 3. NF- $\kappa \mathrm{B}$ in B-cell activation. The activation of follicular B cells by CD4 T-cell-dependent CD40 and BCR signals promotes a rapid antigen-driven expansion of $\mathrm{B}$ cells in the germinal centers (GC) of secondary lymphoid organs that is accompanied by isotype switching and affinity maturation. These antigen and cytokine driven events lead to the development of long-lived plasma cells and memory B cells. Shown are the requirements for NF- $\mathrm{KB}$ during the various phases of B-cell differentiation and proliferation.

(Vallabhapurapu and Karin 2009). Strong BCR signals rapidly lead to the IKK $\beta$-dependent nu-

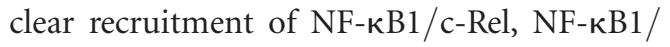
RelA, and NF- $\kappa$ B1 homodimers from cytoplasmic reserves (Kontgen et al. 1995; Grumont et al. 1998). Lipopolysaccharide and CpG double stranded DNA, respective ligands for TLR4 and TLR9, also rapidly activate these same NF-кB complexes (Grumont and Gerondakis 1994; Krieg 2002). In contrast, CD40 signals activate both IKK $\alpha$ and IKK $\beta$ (Hayden and Ghosh 2008; Vallabhapurapu and Karin 2009), resulting in the nuclear expression of both RelB and c-Rel complexes. Although both NF- $\mathrm{B}$ pathways participate in CD40-dependent humoral immunity (Gerondakis et al. 2006; Hayden and Ghosh 2008; Vallabhapurapu and Karin 2009), impaired antibody responses that arise from a block in the alternate NF- $\mathrm{kB}$ pathway are not caused by B-cell intrinsic defects (Franzoso et al. 1998), highlighting the distinct roles served by the two arms of the NF-кB pathway. Cross talk among these receptors is crucial in determining how NF-кB influences functional outcomes during B-cell activation. BCR signals alone, although not able to efficiently trigger B-cell differentiation, nevertheless provide essential costimulatory signals that influence survival and differentiation. BCR induction of NF- $\kappa B$ protects CD40-stimulated B cells from activation-induced cell death (Rothstein et al. 2000) (see later discussion) and prevent B-cell hypo-responsiveness that can accompany continuous TLR signaling (Poovassery et al. 2009). Finally, the duration of $\mathrm{B}$-cell stimulation also influences the temporal regulation of NF- $\kappa \mathrm{B}$ activity. In addition to the initial rapid nuclear induction of NF- $\mathrm{kB}$, sustained TLR4 (Grumont and Gerondakis 1994) and BCR (S.G., unpubl. results) signals lead to multiple, transient waves of nuclear NF- $\mathrm{BB}$ 
expression that are dependent on the "de novo" synthesis of these transcription factors (Grumont and Gerondakis 1994). It remains to be determined which functions during B-cell activation are linked to the specific phases of NF- $\mathrm{B}$ expression.

\section{$\mathrm{NF}-\kappa \mathrm{B}$ and B-cell Division}

Both the IKK $\alpha$ and IKK $\beta$-dependent NF-кB pathways contribute to mitogen-induced B-cell proliferation by regulating multiple B-cell intrinsic mechanisms. BCR, CD40, and TLR4 or TLR9 signals each use the classical NF- $\mathrm{B}$ pathway to promote B-cell proliferation (Ghosh and Hayden 2008; Hayden and Ghosh 2008; Vallabhapurapu and Karin 2009); only CD40 appears to require the alternate pathway for this function (Vallabhapurapu and Karin 2009). All IKK $\beta$ dependent B-cell mitogenic responses require c-Rel (Gerondakis et al 1998), albeit to varying degrees, with BCR activation being most dependent on c-Rel (Grumont et al. 1998). $\mathrm{NF}-\kappa \mathrm{B} 1$ on the other hand is only crucial for
TLR4-dependent B-cell proliferation (Sha et al. 1995; Grumont et al. 1998).

The classical NF- $\kappa \mathrm{B}$ pathway serves several distinct roles in the cell cycle during BCRinduced proliferation (Fig. 4). c-Rel is required for progression from G1 to S-phase (Grumont et al. 1998 ). Although c-Rel regulates cell survival during BCR activation (Grumont et al. 1998, 1999; Cheng et al. 2003), the failure of c-Rel-deficient B cells to proliferate is a direct consequence of a cell cycle block and not merely a secondary consequence of cell death (Grumont et al. 1998; Cheng et al. 2003). The expression of E2F3, an E2F transcription factor involved in G1/S phase progression (Humbert et al. 2000) was shown to be impaired in BCR activated c-Rel-deficient B cells (Cheng et al. 2003). With E2F3 known to contribute to the suppression of p21Cip1 function ( $\mathrm{Wu}$ et al. 2001), c-Rel may promote cell cycle progression by serving to inactivate $\mathrm{Rb}$-dependent repression of S-phase entry. Whether E2F3 is the only direct c-Rel target important in cell

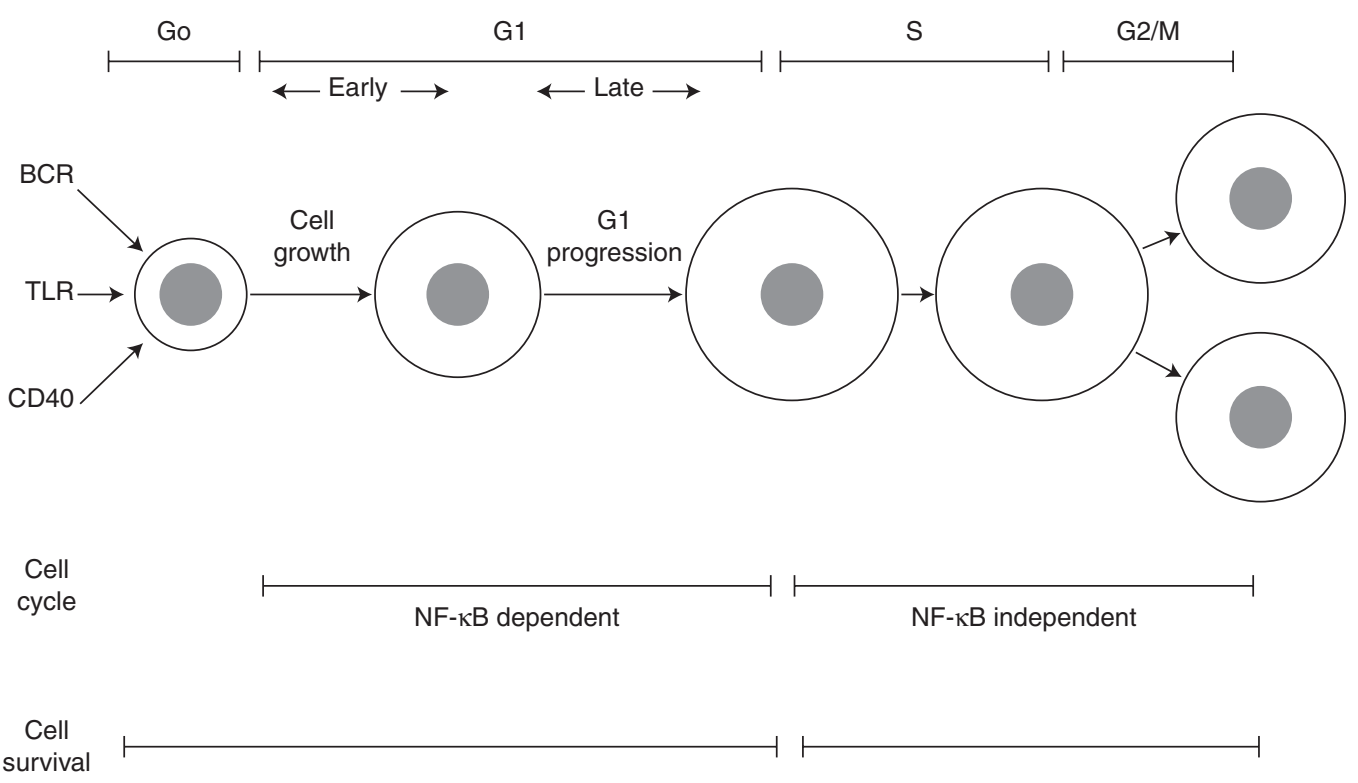

Figure 4. Roles of NF- $\kappa \mathrm{B}$ in B-cell division. Following stimulation through the BCR, CD40, or TLR4/TLR9, mature quiescent B cells in G0 enter G1 and undergo an NF- $\kappa$ B dependent phase of growth. B-cell growth continues until late G1, at which point NF- $\kappa B$ is required for entry into S-phase. Subsequent steps in the B-cell cycle appear to be NF-кB independent. NF-кB also regulates survival signals associated with B-cell activation and division. 
cycle progression remains to be determined. The expression of IRF4, a transcription factor shown to influence normal B cell (Mittrucker et al. 1997) and malignant B cell (Shaffer et al. 2008) proliferation is also impaired in mitogen activated c-Rel-deficient B cells (Grumont and Gerondakis 2000). Despite c-Rel being necessary for BCR or TLR4 entry into $S$ phase (Grumont et al. 1998), these combined signals permit a majority of $B$ cells to progress through the cell cycle in the absence of c-Rel. These findings are consistent with c-Rel setting a threshold for cell cycle progression by modulating the stimulus-dependent transcription of cell cycle regulators. Transcriptional targets of NF-кB1 involved in TLR4-dependent G1 to $S$ phase progression remain to be identified.

c-Rel and NF- $\kappa B 1$ function redundantly to promote cell growth during G0 to G1 progression (Pohl et al. 2002; Grumont et al. 2002). This step in the cell cycle, associated with ribosome biogenesis (Stocker and Hafen 2000), is essential for assembling the cellular machinery necessary for DNA replication. This NF-кBdependent control of $\mathrm{B}$-cell growth, which is required for all activation signals, involves c-Rel and NF- $\mathrm{\kappa B} 1$ inducing the expression of c-Myc (Lee et al. 1995; Grumont et al. 2002), which serves a key role in the growth of eukaryotic cells (Levens 2002). Despite c-Myc transgene expression promoting $\mathrm{B}$-cell growth in the absence of c-Rel and NF-кB1, it is insufficient to drive the mitogen-dependent proliferation of $B$ cells lacking these NF- $\mathrm{kB}$ transcription factors (Grumont et al. 2002), further highlighting the multiple role(s) c-Rel and possibly NF-кB1 serve in B-cell division.

In vivo, B cells undergo extensive antigendependent proliferation in germinal centers linked with BCR affinity maturation that occurs during the development of memory $B$ cells and plasma cells (McHeyzer-Williams 2003). Remarkably, germinal center (GC) B cells fail to express most NF- $\mathrm{KB}$ target genes and NF- $\mathrm{KB}$ pathway components (Shaffer et al. 2001), indicating that NF- $\mathrm{KB}$ signaling appears to be dispensable for GC B-cell proliferation. A strong bias of the GC B-cell gene expression profile toward G2/M regulators rather than cell growth regulators such as ribosomal components (Shaffer et al. 2001) is consistent with a shortened G1 that is characteristic of rapidly dividing GC B cells (McHeyzer-Williams 2003). The findings that the NF- $\kappa B$ pathway appears to be important for initiating the proliferation of naïve B cells, but not the division of GC B cells during differentiation, reinforces the link between NF- $\mathrm{BB}$ and G0/G1 control of the cell cycle. It also highlights how selective engagement of the NF- $\kappa B$ pathway during different stages of B-cell activation and differentiation can be used to control the rate of B-cell division.

\section{NF- $\kappa$ B Control of Activated B-cell Survival}

Elevated levels of apoptosis typically accompany B-cell activation. The prevailing models favor apoptosis in this instance as a mechanism used to eliminate B cells that are not programmed to undergo normal cell division. Such models are consistent with c-Rel-controlling BCR and TLR4-induced division and survival through the regulation of distinct target genes (Grumont et al. 1998, 1999; Cheng et al. 2003). The viability of BCR-activated B cells is dependent on c-Rel directly inducing the transcription of genes encoding the $\mathrm{Bcl}-2$ prosurvival homologs, A1/Blf1 (Grumont et al. 1999) and Bcl-xL (Cheng et al. 2003). Although the coexpression of two related antiapoptotic genes has been viewed as a redundant, fail-safe survival mechanism (Lee et al. 1999), neither overexpression of A1 (Grumont e al. 1999) or Bcl-xL (S.G., unpubl. results) alone is sufficient to confer complete protection to BCR-activated $B$ cells lacking c-Rel. However, with enforced Bcl-2 transgene expression able to block the BCR induced death of c-Rel deficient B cells (Grumont et al. 1998), thereby ruling out any involvement of the death receptor pathway, this reinforces the notion that $\mathrm{Al}$ and $\mathrm{Bcl}-\mathrm{xL}$ serve distinct survival roles. With the c-Rel induction of A1 preceding $\mathrm{Bcl}-\mathrm{xL}$ in activated $\mathrm{B}$ cells (Grumont et al. 1999; Cheng et al. 2003), it is conceivable that A1-mediated B-cell survival is linked to early events in the cell cycle, such as cell growth, whereas Bcl-xL prevents death associated with the G1 to $S$ phase transition. 
Unlike cell death associated with BCR activation, which is limited by c-Rel alone, both NF-кB1 and c-Rel cooperate to protect TLR4stimulated B cells from apoptosis (Gerondakis et al. 2007). This cell death, driven by activation of the BH3-only proapoptotic protein Bim is blocked by c-Rel and NF- $\kappa \mathrm{B} 1$ regulating distinct survival pathways (Gerondakis et al. 2007; Banerjee et al. 2008). c-Rel induction of $A 1$ and Bcl-xL coincide with both survival proteins binding to Bim, thereby preventing it from engaging the cell intrinsic death pathway. NF-кB1 indirectly inhibits TLR4-induced death by controlling ERK phosphorylation of Bim (Banerjee et al. 2008), a posttranslational event that targets Bim for degradation (Ewings et al. 2007). NF- $\kappa \mathrm{B} 1$ and ERK activation are linked through the NF- $\mathrm{KB} 1$ precursor, p105 serving as a scaffold for the ERK pathway specific MAP3 kinase, Tpl2 (Belich et al. 1999). Following TLR4 activation, IKK $\beta$-induced phosphorylation and degradation of p105 serves as an essential step in Tpl2 activation (Waterfield et al. 2003; Banerjee et al. 2005). It remains to be determined if these distinct NF-кB-regulated survival mechanisms neutralize Bim in a spatial or temporal manner.

CD40 serves opposing roles in B-cell survival. In isolation, CD40 signals are able to promote B-cell survival through the NF- $\mathrm{B}$ induction of A1 and Bcl-xL (Lee et al. 1999). However, under physiological conditions in which antigen-stimulated helper T cells express high levels of CD40 ligand, CD40 signals sensitize B cells to Fas-induced apoptosis (Rothstein et al. 2000). This death, which is prevented by costimulating B cells through the BCR, ensures that only appropriate antigen-specific B cells and not bystander cells are activated by CD40 (Rothstein et al. 2000). This BCR-induced protection of CD40-sensitized B cells is independent of c-Rel (Owyang et al. 2001) and requires the PI3K/AKT-dependent induction of c-FLIP (Moriyama and Yonehara 2007), a caspase-8 inhibitor essential for death-receptor-induced apoptosis (Strasser et al. 2009). Although the NF-кB pathway activated through CD40 has been shown in certain cell line models to prevent Fas-induced B-cell death (Lee et al. 1999; Zazzeroni et al. 2003), these seemingly paradoxical findings may be reconciled with CD40 alone serving to protect B cells from transient, but not sustained Fas signals (Lee et al. 1999). With death-receptor-induced apoptosis largely resistant to prosurvival signals emanating from the cell intrinsic survival pathway (Strasser et al. 2009), CD40 induction of Bcl-xL and A1 most likely serves to prevent death linked to CD40-induced cell division.

\section{Isotype Switching}

NF- $\kappa \mathrm{B}$ signaling is essential for isotype switching (Hayden et al. 2006), a mechanism used to fine-tune humoral immune responses that involves the transposition of the assembled VDJ gene located upstream of $\mathrm{C} \mu$ to a downstream heavy chain $\left(\mathrm{C}_{\mathrm{H}}\right)$ gene. T-independent antigens and T-cell-dependent CD40 signals, in combination with specific cytokines, direct switching to specific classes of immunoglobulin (Manis et al. 2002). In the mouse, for example, LPS promotes switching to IgG3, whereas CD40 signals and IL-4 produced by Th2 T cells promote switching to IgG1 and IgE (Manis et al. 2002). Switch recombination occurs between regions of repeat sequence (S-regions) located upstream of each $\mathrm{C}_{\mathrm{H}}$ gene. $\mathrm{S}$-region transcription activated by mitogen and cytokine-induced binding of proteins to cryptic promoters (I regions) flanking S-regions facilitates S-region access to the DNA recombination machinery (Manis et al. 2002). NF- $\kappa$ B transcription factors downstream of the classical and alternate pathways participate in switching through a variety of mechanisms (Hayden et al. 2006). NF- $\kappa$ B factors induced by mitogens and cytokines promote S-region transcription by binding to specific I regions (Delphin and Stavnezer 1995; Agresti and Vercelli 2002; Bhattacharya et al. 2002; Wang et al. 2006). Switching is also dependent on NF- $\mathrm{\kappa B}$ factors binding to the $3^{\prime}$ IgH enhancer, a locus control region located downstream of the $\mathrm{C} \alpha$ gene (Zelazowski et al. 2000; Laurencikiene et al. 2001). Although NF-кB does not regulate the expression of the switch recombination enzymes (Chaudhuri et al. 2007), NF-кB1 has been implicated in the DNA rearrangement process (Kenter et al. 2004), and given DNA 
synthesis is essential for S-region rearrangement (Chaudhari et al. 2007), NF-кB signaling also probably indirectly influences switching through the promotion of B-cell proliferation.

\section{NF-кB AND T-CELL ACTIVATION}

The successful activation of naïve $\mathrm{T}$ cells requires two distinct signals: an antigen-specific signal arising from TCR engaging MHC bound peptides expressed on APC, plus a costimulatory signal in the form of the B7 ligand upregulated on APC that binds to CD28. These signals, in addition to inducing the rapid expression of IL-2 and activation-associated cell surface molecules, promote $\mathrm{T}$-cell division and effector T-cell differentiation along different lineages, the later of which is dictated by cytokine signals. The careful regulation of T-cell numbers before, during, and following immune responses by controlling the competing mechanisms of cell survival and apoptosis, serve to prevent immune-related pathology associated with inappropriate T-cell expansion and function. Those stages during T-cell activation and differentiation that involve NF- $\mathrm{NB}$ function are summarized in Figure 5.

Before antigen activation, naïve CD4 and CD8 $\mathrm{T}$ cells express very low levels of NF- $\mathrm{B} 1$ in the nucleus. In contrast to $\mathrm{B}$ cells, the absence of constitutive NF- $\kappa \mathrm{B}$ activity in these T cells is consistent with this pathway being dispensable for the homeostatic survival of naïve T cells. Following TCR and costimulatory signals, different NF- $\kappa$ B proteins enter the nucleus in a temporally regulated fashion (Molitor et al. 1990). Initially, pre-exisiting NF- $\mathrm{B} 1 /$ RelA dimers bound to Ік $\mathrm{B} \alpha$ are rapidly transported to the nucleus (Molitor et al. 1990; Venkataraman et al. 1996). Although c-Rel is present in the cytoplasm of naïve T cells, it is not rapidly mobilized by TCR signals (Venkataraman et al. 1995; Rao et al. 2003) due to its association with IкB $\beta$ (Banerjee et al. 2005), which is relatively resistant to degradation triggered by the initial TCR stimulus. Significant nuclear levels of c-Rel, which follow NF-кB1/RelA expression, depend on the TCRdependent induction of $c$-rel transcription (Grumont and Gerondakis 1990; Venkataraman et al. 1996; Rao et al. 2003). TCR-induced c-Rel expression is NFAT dependent (Venkataraman et al. 1995), consistent with c-Rel being a direct transcriptional target of NFAT (Grumont et al. 2004). Although c-Rel is necessary for the induction of IL-2 (seelater discussion) following T-cell activation, the role served by the initial wave of NF-кB1/RelA expression remains unclear, although it may be related to cell-cycle control as reflected by the impaired proliferation of TCR-activated RelA-deficient T cells (Doi et al. 1997).

\section{NF- $\kappa \mathrm{B}$ and T-cell Proliferation}

Both the classical and alternate NF- $\kappa$ B pathways regulate $\mathrm{T}$-cell proliferation in culture and "in vivo" via T-cell autonomous and nonautonomous mechanisms (Gerondakis et al. 2006; Vallabhapurapu and Karin 2009). NF-кB signaling is pivotal in controlling the proliferation of naïve T cells (Gerondakis et al. 2006). NF- $\kappa$ B1, c-Rel, and RelA serves unique (Kontgen et al. 1995; Gerondakis et al. 2006; Doi et al. 1997; Sriskantharajah et al. 2009) and overlapping roles (Gerondakis et al.2006) in T-cell proliferation during different stages of the cell cycle. In contrast to B cells, which require NF- $\mathrm{KB} 1$ or $\mathrm{c}-\mathrm{Rel}$ to induce mitogen-dependent T-cell growth (Grumont et al. 2002), it is RelA and c-Rel that function redundantly to promote c-Myc-induced T-cell growth following TCR activation (Grumont et al. 2004). Although c-Myc expression is both necessary and sufficient to promote T-cell growth in the absence of NF- $\kappa \mathrm{B}$ function, it is not to rescue the TCR-induced proliferation of NF-кB-deficient T cells (Grumont et al. 2004). Therefore, the combined activity of these transcription factors, as well NF-кB1 and c-Rel (Zheng et al. 2003), serve functions in addition to growth, which are required for T-cell proliferation. The finding that IKK2-deficient CD4 T cells proliferate in culture as effectively as normal cells in response to a range of strong polyclonal stimuli (Schmidt-Supprian et al. 2003) is seemingly at odds with the findings for T-cell proliferation that emerge from the analysis of the different NF- $\kappa \mathrm{B}$ compound mutant mice. This can be reconciled by the ability of the residual 


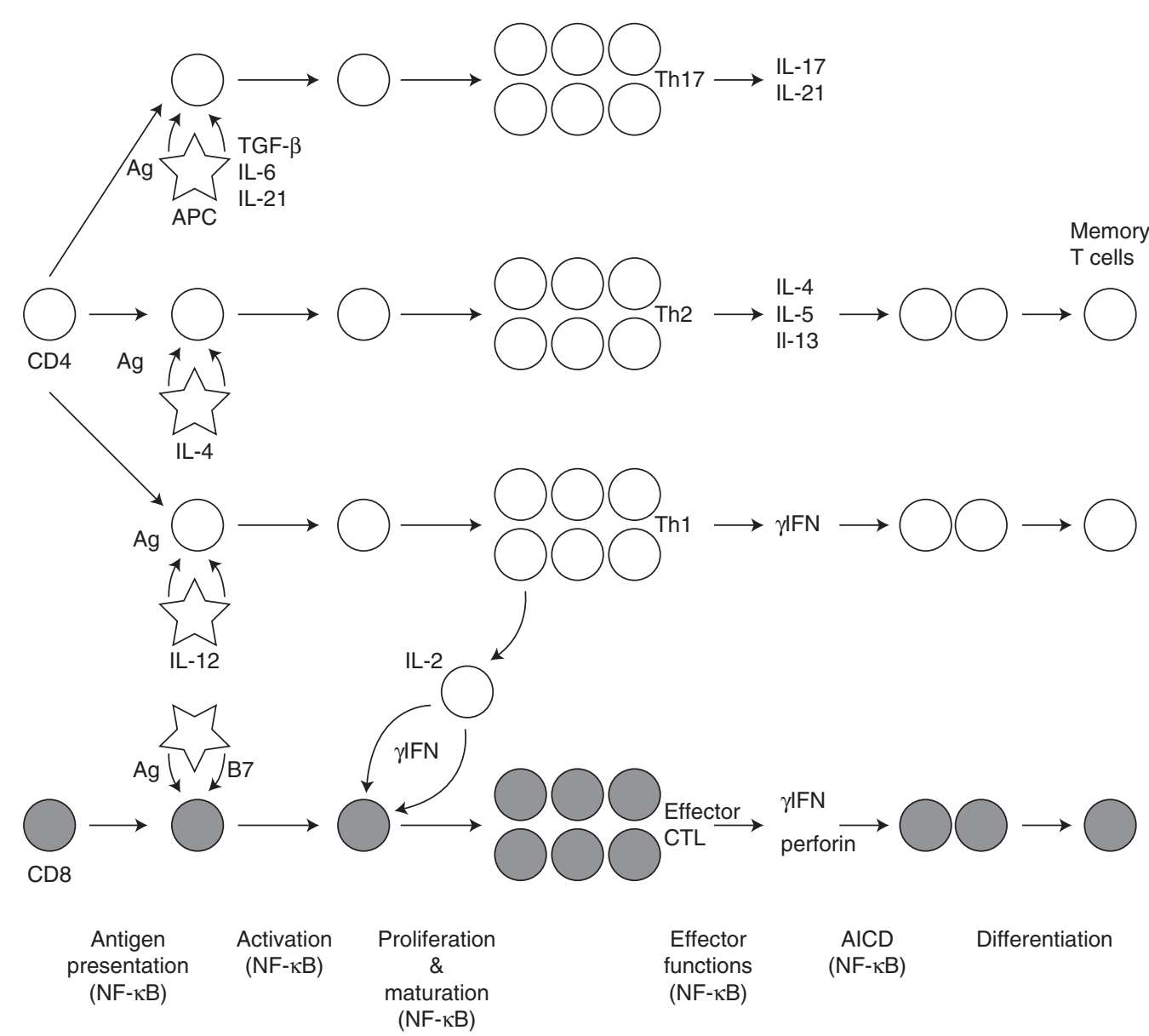

Figure 5. NF-кB in conventional T-cell activation. TCR-dependent activation of naïve CD4 and CD8 T cells by antigen presenting cells (APC) leads to T-cell activation, division, and effector T-cell differentiation. The various CD4 $\mathrm{T}$ helper cell subsets and CD8 cytotoxic $\mathrm{T}$ lymphocytes that develop in response to different cytokine and costimulatory signals delivered by APC and T cells undergo rapid antigen-driven expansion during the course of an infection. Following pathogen elimination, most effector T cells undergo activationinduced cell death, with the few surviving antigen-specific $\mathrm{T}$ cells differentiating into long-lived memory cells. Highlighted are roles for NF-кB in APC function, T-cell activation, CD4 Th differentiation, and T-cell survival and proliferation.

NEMO/IKK $\alpha$ complexes in IKK $\beta$-deficient CD4 $\mathrm{T}$ cells to phosphorylate $\mathrm{I} \kappa \mathrm{B} \alpha$ and induce a normal pattern of NF-кB complexes following T-cell activation (Schmidt-Supprian et al. 2003). However, the inability of OVA or KLH antigenspecific IKK $\beta$-deficient $\mathrm{T}$ cells to proliferate in culture following restimulation with these same antigens that had previously been used to immunize mice in which IKK $\beta$ was selectively deleted in CD4 T lineage cells (Schmidt-Supprian et al. 2004b) suggests that IKK $\alpha$ can only activate NF- $\mathrm{NB}$ complexes normally induced by IKK $\beta$ in response to strong stimuli.

IL-2, which is involved in autocrine-mediated T-cell proliferation, is dependent on c-Rel for its induction following TCR and costimulatory signaling (Kontgen et al. 1995). c-Rel appears to induce $i l 2$ transcription in response to TCR and CD28 stimulation by remodeling chromatin in the vicinity of the CD28 response region of the IL-2 promoter, so that it is now conducive to transcription (Rao et al. 2003; 
Chen et al. 2005). Despite c-Rel being essential for IL-2 dependent CD4 T-cell proliferation in culture (Kontgen et al. 1995), this cytokine is dispensable for conventional T-cell proliferation in vivo (Schimpl et al. 2002). Instead, IL-2-deficient mice develop lymphoproliferative and autoimmune disease caused by impaired CD4 regulatory T-cell development (Liston and $\mathrm{Ru}$ densky 2007). Although c-Rel-deficient mice have reduced numbers of $\mathrm{CD} 4$ regulatory $\mathrm{T}$ cells, this is caused by IL-2-independent mechanisms (S.G., unpubl. results). The failure of c-Rel-deficient mice to develop autoimmune disease indicates that IL-2 expression can be controlled in a c-Rel-independent fashion in vivo.

Although the mechanisms by which NF-кB controls T-cell proliferation in culture are reasonably well established, NF- $\mathrm{\kappa B}$ regulation of $\mathrm{T}$-cell proliferation in vivo is complex, with an in depth overview beyond the scope of this article. Nevertheless, it is clear that the extent to which the NF- $\kappa \mathrm{B}$ pathway contributes to T-cell proliferation in vivo is dictated by the type of $\mathrm{T}$ cell, its state of differentiation, plus the nature and strength of the T-cell stimulatory signals. For example, the homeostatic expansion of naïve CD4 and CD8 T cells in a lymphopenic environment is absolutely dependent on IKK $\beta$ (Schmidt-Supprian et al. 2004b). Although IKK $\beta$ is not essential for polyclonal T-cell expansion in vivo that is driven by strong mitogenic stimuli such as super antigens (Schmidt-Supprian et al. 2004b), it does serve a nonredundant T-cell-intrinsic role in the antigen-dependent proliferation that accompanies a recall response (Schmidt-Supprian et al. $2004 \mathrm{~b}$ ). These results, supported by in vitro findings, indicate that IKK $\beta$ function is only dispensable for T-cell proliferation in vivo that is induced by strong TCR signals. Despite some confusion about the roles of NF- $\mathrm{KB}$ in TCR-induced $\mathrm{T}$-cell proliferation that arise from the overlap of IKK $\alpha$ and IKK $\beta$-dependent functions, individual NF- $\kappa \mathrm{B}$ transcription factors do serve select roles in the T-cell proliferative responses triggered by infectious agents. In the case of c-Rel, it serves a T-cell-intrinsic role in the clonal expansion of Th1 effector cells responding to Toxoplasma gondii (Mason et al.
2004), whereas it is dispensable for the expansion of antigen-specific CD8 cytotoxic effector $T$ cells during the primary response to influenza virus (Harling-McNabb et al. 1999). Although $\mathrm{NF}-\kappa \mathrm{B}$ is involved in the proliferative response of effector T cells, it remains to be determined whether this pathway features in the rapid clonal expansion of CD4 and CD8 memory T cells following antigen recall.

\section{NF- $\kappa B$ and T-cell Survival}

NF- $\kappa$ B regulates T-cell survival during antigendependent activation and proliferation by controlling both the cell intrinsic and death receptor pathways. Controversy that surrounds how some aspects of how T-cell survival is controlled appears to reflect the complexity of a process that is intimately linked to the strength and duration of immune signals.

TCR and costimulatory signals exploit the NF- $\kappa B$ pathway to promote T-cell survival following antigen-dependent activation. NF- $\mathrm{B}$ activation triggered through antigen-dependent TCR recruitment of the IKK complex to a signaling hub at the immunological synapse that requires PKCO and the signaling components CARM1, Bcl-10, and MALT1 (Weil and Israel 2006) appears to afford different degrees of protection to CD4 and CD8 T cells. Following TCR activation, PKC $\theta$ is critical for CD8 T-cell survival, which is mediated via c-Rel (Saibil et al. 2007). Although c-Rel is necessary for the induction of Bcl-xL, expression of this antiapoptotic molecule alone appears to be insufficient to confer protection from TCR-induced cell death (Saibil et al. 2007). In contrast, PKC $\theta$ only serves a modest role in CD4 T-cell survival, which surprisingly is not dependent on either NF-кB1 or c-Rel (Saibil et al. 2007). However, the finding that a combined deficiency of c-Rel and NF- $\kappa$ B1 has a profound impact on TCR-induced CD4 T-cell survival (Zheng et al. 2003) points to these transcription factors serving overlapping survival roles, presumably mediated through PCK $\theta$ dependent and independent pathways. This difference serves to highlight that the NF- $\kappa B$ survival signals delivered through the TCR are programmed 
differently in CD4 and CD8 T cells. The NF-кB pathway also exploits or is used by the T-cell costimulatory molecules OX40 (CD134) and glucocorticoid induced TNF receptor (GITR) to promote the survival of activated $\mathrm{T}$ cells (Song et al. 2008; Zhan et al. 2008). In the case of GITR, NF-кB-dependent expression of this coreceptor on TCR-stimulated CD4 and CD8 T cells, appears to serve as a mechanism for promoting T-cell survival in response to weak, rather than strong TCR signals (Zhan et al. 2008).

NF- $\kappa \mathrm{B}$ also serves as a lynch pin in coordinating cell survival during T-cell proliferation. Following TCR-dependent antigen stimulation, successful S-phase entry associated with the upregulation of E2F target gene expression and cyclin E-dependent kinase activity requires NF-кB to neutralize p73-induced apoptosis (Wan and DeGregori 2003). In the absence of appropriate signals that activate NF- $\mathrm{B}$ during G1, although E2F activation and the capacity to enter $S$ phase remains intact, cell death is triggered by CDK2-dependent p73 expression. To restrict the number of activated $\mathrm{T}$ cells during immune responses, ongoing $\mathrm{T}$-cell proliferation associated with persistent TCR stimulation promotes activation-induced T-cell death (AICD) by engaging the death receptor Fas (Strasser et al. 2009). TCR-dependent activation of the $\mathrm{NF}-\kappa \mathrm{B}$ pathway through its inhibition of caspase-8 activation helps counter Fas-induced T-cell death (Jones et al. 2005). It remains to be determined how in the face of continuous TCR signals, T cells sense a need to prevent or succumb to AICD by regulating NF- $\kappa$ B activation. Once pathogenic agents have been eliminated, a small number of antigen-specific CD4 or CD8 effector $\mathrm{T}$ cells survive and differentiate into long-lived memory $\mathrm{T}$ cells capable of mounting rapid immune responses on recountering the pathogen. It remains to be determined if NF- $\kappa \mathrm{B}$ signaling is required for memory T-cell survival.

\section{NF- $\kappa \mathrm{B}$ and Effector T-cell Differentiation}

Naïve T can adopt a number of developmental options that are dictated by the types of signals these cells encounter during antigen-dependent activation. In the case of CD4 T helper cells (Th), these include Th1, Th2, Th17, and Tregulatory cells, all of which are distinguished by the types of cytokines these cells produce (Fig. $5)$. The NF-кB pathway regulates CD4 Th differentiation through APC-dependent and T-cell intrinsic mechanisms. Aside from the role NF- $\kappa$ B plays in antigen-dependent and independent differentiation of certain dendritic cell (DC) subsets (Ouaaz et al. 2002; O'Keeffe et al. 2005), the NF-кB-regulated expression of specific cytokines in these key APC, influences Th cell differentiation and function. c-Rel, for example, which is required for Th1 immune responses (Gerondakis et al. 2006), is crucial for DC expression of $\mathrm{p} 35$, a subunit of the cytokine IL-12 that is essential in Th1 development (Grumont et al. 2001). The finding that in activated DC, c-Rel controls the expression of IL-12 (Grumont et al. 2001), whereas RelA is more important in regulating the production of inflammatory cytokines such as IL-1, IL-6, and TNF (Wang et al. 2007) that are involved in shaping Th17 responses (Laurence and O'Shea 2007), may indicate that the antigen-dependent activation of specific NF- $\mathrm{B}$ complexes in DC, in part influences the outcome of Th cell development. However, a flexible rather than strict bifurcation of inflammatory versus regulatory cytokine production controlled by different NF- $\kappa \mathrm{B}$ factors is more likely, with c-Rel in certain instances implicated in the expression of inflammatory cytokines such as TNF (Grigoriadis et al. 1996) and IL-23 (Mise-Omata et al. 2007). In contrast to the role of c-Rel in Th1 but not Th2 differentiation, NF- $\mathrm{KB} 1$ selectively regulates Th2 cell differentiation (Das et al. 2001). T cells lacking NF- $\kappa$ B1 fail to induce GATA3 expression, a transcription factor crucial in the differentiation of Th2 cells. The role of NF- $\kappa \mathrm{B} 1$ in Th2 cells appears to be restricted to the development rather than the function of committed Th2 cells, with NF-кB1-deficient mice failing to mount airway inflammatory responses, a defect that coincides with the inability to produce the Th2 signature cytokines IL-4, IL-5, and IL-13 (Das et al. 2001).

In addition to helping polarize $\mathrm{T}$-cell responses linked with the production of specific 
cytokines, NF- $\kappa \mathrm{B}$ transcription factors also regulate cytokine gene expression in activated $\mathrm{T}$ cells. Aside from NF-кB having a direct role in the TCR and costimulatory signal dependent transcription of cytokine genes that include IL-2, GM-CSF, IL-3, and IFN- $\gamma$ (Gerondakis et al. 2006), cytokine production by naïve T cells can be enhanced by the TLR-dependent induction in APC of T-cell costimulatory molecules and cytokines that alter c-Rel responsiveness during TCR activation (Banerjee et al. 2005). In naïve $T$ cells, which are notoriously refractory for cytokine production, c-Rel is primarily bound to I $\mathrm{B}-\beta$, which is relatively resistant to degradation triggered by TCR signals. T cells exposed to the pro-inflammatory cytokines TNF- $\alpha$ and IL-1, shift c-Rel to I $\mathrm{B}$ - $\alpha$-associated complexes that are readily targeted by the TCR. As a consequence, in cytokine-primed T cells, IL-2 and IFN- $\gamma$ mRNA are now produced rapidly, and at higher levels.

Finally, little is currently known about the genetic programs that regulate the development of memory cells from the pool of effector $\mathrm{T}$ cells. Despite an essential role for NF- $\kappa \mathrm{B}$ function in memory T-cell development (SchmidtSupprian et al. 2003), it remains unclear whether this dependence on the NF- $\kappa \mathrm{B}$ pathway reflects a direct role in memory cell differentiation or a maintenance role through the control of memory cell survival.

\section{CONCLUDING REMARKS}

Despite remarkable progress in understanding the roles of the NF- $\kappa \mathrm{B}$ pathway in normal lymphocyte development and function, much still remains to be learned. Areas in need of greater attention include gaining a better understanding of how NF- $\mathrm{B}$ controls the development of the innate $\mathrm{T}$-cell lineages, determining what roles the NF- $\kappa \mathrm{B}$ pathway serves in memory T-cell differentiation, and cataloging the many and varied roles the NF- $\mathrm{B}$ pathway serves in lymphocytes during different types of infectious diseases. With NF- $\mathrm{B}$ involvement being documented in an increasing number of lymphoid-associated pathologies, answers to these and a range of other outstanding questions will serve as a basis for preventing and treating these diseases.

\section{REFERENCES}

Agresti A, Vercelli D. 2002. c-Rel is a selective activator of a novel IL-4/CD40 responsive element in the human Ig $\gamma 4$ germline promoter. Mol Immunol 38: 849-859.

Aifantis I, Mandal M, Sawai K, Ferrando A, Vilimas T. 2006. Regulation of T-cell progenitor survival and cell-cycle entry by the pre-T-cell receptor. Immunol Rev 209: $159-169$.

Akiyama T, Shimo Y, Yanai H, Qin J, Ohshima D, Maruyama Y, Asaumi Y, Kitazawa J, Takayanagi H, Penninger JM, et al. 2008. The tumor necrosis factor family receptors RANK and CD40 cooperatively establish the thymic medullary microenvironment and self-tolerance. Immunity 29: $423-437$.

Allen CD, Cyster JG. 2008. Follicular dendritic cell networks of primary follicles and germinal centers: phenotype and function. Semin Immunol 20: 14-25.

Allman D, Pillai S. 2008. Peripheral B cell subsets. Curr Opin Immunol 20: 149-157.

Banerjee D, Liou HC, Sen R. 2005. c-Rel-dependent priming of naive T cells by inflammatory cytokines. Immunity 23: 445-458.

Banerjee A, Grumont R, Gugasyan R, White C, Strasser A, Gerondakis S. 2008. NF- $\kappa \mathrm{B} 1$ and c-Rel cooperate to promote the survival of TLR4-activated B cells by neutralizing Bim via distinct mechanisms. Blood 112: 5063-5073.

Banerjee A, Gugasyan R, McMahon M, Gerondakis S. 2006 Diverse Toll-like receptors utilize Tpl2 to activate extracellular signal-regulated kinase (ERK) in hemopoietic cells. Proc Natl Acad Sci 103: 3274-3279.

Barnes MJ, Krebs P, Harris N, Eidenschenk C, GonzalezQuintial R, Arnold CN, Crozat K, Sovath S, Moresco EM, Theofilopoulos AN, et al. 2009. Commitment to the regulatory $\mathrm{T}$ cell lineage requires CARMA1 in the thymus but not in the periphery. PLoS Biol 7: e51.

Basak S, Kim H, Kearns JD, Tergaonkar V, O’Dea E, Werner SL, Benedict CA, Ware CF, Ghosh G, Verma IM, et al.

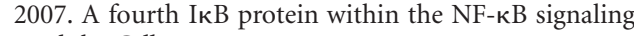
module. Cell 128: 369-381.

Batista FD, Harwood NE. 2009. The who, how and where of antigen presentation to B cells. Nat Rev Immunol 9: 15-27.

Belich MP, Salmerón A, Johnston LH, Ley SC. 1999. TPL-2 kinase regulates the proteolysis of the NF- $\mathrm{BB}$-inhibitory protein NF-кB1 p105. Nature 397: 363-368.

Bhattacharya D, Lee DU, Sha WC. 2002. Regulation of Ig class switch recombination by NF-кB: Retroviral expression of RelB in activated B cells inhibits switching to IgG1, but not to IgE. Int Immunol 14: 983-991.

Boehm T. 2008. Thymus development and function. Curr Opin Immunol 20: 178-184.

Bommhardt U, Beyer M, Hünig T, Reichardt HM. 2004. Molecular and cellular mechanisms of T cell development. Cell Mol Life Sci 61: 263-280.

Boothby MR, Mora AL, Scherer DC, Brockman JA, Ballard DW. 1997. Perturbation of the T lymphocyte lineage in 
transgenic mice expressing a constitutive repressor of nuclear factor (NF)-кB. J Exp Med 185: 1897-1907.

Bredemeyer AL, Helmink BA, Innes CL, Calderon B, McGinnis LM, Mahowald GK, Gapud EJ, Walker LM, Collins JB, Weaver BK, et al. 2008. DNA double-strand breaks activate a multi-functional genetic program in developing lymphocytes. Nature 456: 819-823.

Brown KD, Claudio E, Siebenlist U. 2008. The roles of the classical and alternative nuclear factor- $\mathrm{\kappa B}$ pathways: Potential implications for autoimmunity and rheumatoid arthritis. Arthritis Res Ther 10: 212.

Burrows PD, Kronenberg M, Taniguchi M. 2009. NKT cells turn ten. Nat Immunol 10: 669-671.

Caamaño JH, Rizzo CA, Durham SK, Barton DS, RaventósSuárez C, Snapper CM, Bravo R. 1998. Nuclear factor (NF)-к B2 (p100/p52) is required for normal splenic microarchitecture and B cell-mediated immune responses. $J$ Exp Med 187: 185-96.

Cadera EJ, Wan F, Amin RH, Nolla H, Lenardo MJ, Schlissel MS. 2009. NF- $\kappa$ B activity marks cells engaged in receptor editing. J Exp Med 206: 1803-1816.

Cariappa A, Liou HC, Horwitz BH, Pillai S. 2000. Nuclear factor $\kappa \mathrm{B}$ is required for the development of marginal zone B lymphocytes. J Exp Med 192: 1175-1182.

Castro I, Wright JA, Damdinsuren B, Hoek KL, Carlesso G, Shinners NP, Gerstein RM, Woodland RT, Sen R, Khan WN. 2009. B cell receptor-mediated sustained c-Rel activation facilitates late transitional B cell survival through control of B cell activating factor receptor and NF-кB2. J Immunol 182: 7729-7737.

Caton AJ, Cozzo C, Larkin J, Lerman MA 3rd, Boesteanu A, Jordan MS. 2004. CD4 (+) CD25(+) regulatory T cell selection. Ann N Y Acad Sci 1029: 101-114.

Chaudhuri J, Basu U, Zarrin A, Yan C, Franco S, Perlot T, Vuong B, Wang J, Phan RT, Datta A, et al. 2007. Evolution of the immunoglobulin heavy chain class switch recombination mechanism. Adv Immunol 94: 157-214.

Chen X, Wang J, Woltring D, Gerondakis S, Shannon MF. 2005. Histone dynamics on the interleukin-2 gene in response to T-cell activation. Mol Cell Biol 25: 32093219.

Cheng S, Hsia CY, Feng B, Liou ML, Fang X, Pandolfi PP, Liou HC. 2009. BCR-mediated apoptosis associated with negative selection of immature B cells is selectively dependent on Pten. Cell Res 19: 196-207.

Cheng S, Hsia CY, Leone G, Liou HC. 2003. Cyclin E and Bcl-xL cooperatively induce cell cycle progression in c-Rel-/- B cells. Oncogene 22: 8472-8486.

Claudio E, Brown K, Park S, Wang H, Siebenlist U. 2002. BAFF-induced NEMO-independent processing of NF- $\kappa$ B2 in maturing B cells. Nat Immunol 3: 958-965.

Claudio E, Brown K, Siebenlist U. 2006. NF-кB guides the survival and differentiation of developing lymphocytes. Cell Death Differ 13: 697-701.

Claudio E, Saret S, Wang H, Siebenlist U. 2009. Cell-autonomous role for NF- $\kappa$ B in immature bone marrow B cells. J Immunol 182: 3406-3413.

Courtois G. 2008. Tumor suppressor CYLD: Negative regulation of NF-kB signaling and more. Cell Mol Life Sci 65: $1123-1132$.
Das J, Chen CH, Yang L, Cohn L, Ray P, Ray A. A critical role for NF- $\mathrm{B}$ B in GATA3 expression and TH2 differentiation in allergic airway inflammation. Nat Immunol 2: 45-50.

Davis RE, Brown KD, Siebenlist U, Staudt LM. 2001. Constitutive nuclear factor $\mathrm{\kappa B}$ activity is required for survival of activated B cell-like diffuse large B cell lymphoma cells. J Exp Med 194: 1861-1874.

Delphin S, Stavnezer J. 1995. Characterization of an interleukin 4 (IL-4) responsive region in the immunoglobulin heavy chain germline $\epsilon$ promoter: Regulation by NF-IL-4, a C/EBP family member and NF-к B/p50. J Exp Med 181: 181-192.

Denk A, Wirth T, Baumann B. 2000. NF-кB transcription factors: Critical regulators of hematopoiesis and neuronal survival. Cytokine Growth Factor Rev 11: 303-320.

Derudder E, Cadera EJ, Vahl JC, Wang J, Fox CJ, Zha S, van Loo G, Pasparakis M, Schlissel MS, SchmidtSupprian M, et al. 2009. Development of immunoglobulin lambda-chain-positive B cells, but not editing of immunoglobulin $\kappa$-chain, depends on NF- $\mathrm{KB}$ signals. Nat Immunol 10: 647-654.

Doi TS, Takahashi T, Taguchi O, Azuma T, Obata Y. 1997. NF-к B RelA-deficient lymphocytes: Normal development of T cells and B cells, impaired production of IgA and IgG1 and reduced proliferative responses. $J$ Exp Med 185: 953-61.

Drayton DL, Liao S, Mounzer RH, Ruddle NH. 2006. Lymphoid organ development: From ontogeny to neogenesis. Nat Immunol 7: 344-353.

Elewaut D, Ware CF. 2007. The unconventional role of LT $\alpha \beta$ in $\mathrm{T}$ cell differentiation. Trends Immunol 28: $169-175$.

Elewaut D, Shaikh RB, Hammond KJ, De Winter H, Leishman AJ, Sidobre S, Turovskaya O, Prigozy TI, Ma L, Banks TA, et al. 2003. NIK-dependent RelB activation defines a unique signaling pathway for the development of $\mathrm{V} \alpha$ 14i NKT cells. J Exp Med 197: 1623-1633.

Evans I, Kim MY. 2009. Involvement of lymphoid inducer cells in the development of secondary and tertiary lymphoid structure. BMB Rep 42: 189-193.

Ewings KE, Wiggins CM, Cook SJ. 2007. Bim and the prosurvival Bcl-2 proteins: Opposites attract, ERK repels. Cell Cycle 6: 2236-2240.

Felli MP, Vacca A, Calce A, Bellavia D, Campese AF, Grillo R, Di Giovine M, Checquolo S, Talora C, Palermo R, et al. 2005. PKC $\theta$ mediates pre-TCR signaling and contributes to Notch3-induced T-cell leukemia. Oncogene 24: 992-1000.

Feng B, Cheng S, Hsia CY, King LB, Monroe JG, Liou HC. 2004. NF-кB inducible genes BCL-X and cyclin E promote immature B-cell proliferation and survival. Cell Immunol 232: 9-20.

Feng B, Cheng S, Pear WS, Liou HC. 2004. NF-kB inhibitor blocks B cell development at two checkpoints. Med Immunol 3: 1.

Ferch U, zum Büschenfelde CM, Gewies A, Wegener E, Rauser S, Peschel C, Krappmann D, Ruland J. 2007. MALT1 directs B cell receptor-induced canonical nuclear factor- $\kappa \mathrm{B}$ signaling selectively to the $\mathrm{c}-\mathrm{Rel}$ subunit. Nat Immunol 8: 984-991. 
S. Gerondakis and U. Siebenlist

Ferguson AR, Corley RB. 2005. Accumulation of marginal zone B cells and accelerated loss of follicular dendritic cells in NF- $\mathrm{B}$ p50-deficient mice. BMC Immunol 18: 8.

Förster R, Davalos-Misslitz AC, Rot A. 2008. CCR7 and its ligands: Balancing immunity and tolerance. Nat Rev Immunol 8: $362-371$.

Franki AS, Van Beneden K, Dewint P, Hammond KJ, Lambrecht S, Leclercq G, Kronenberg M, Deforce D, Elewaut D. 2006. A unique lymphotoxin $\{\alpha\} \beta$-dependent pathway regulates thymic emigration of $\mathrm{V}\{\alpha\} 14$ invariant natural killer T cells. Proc Natl Acad Sci 103: 9160-9165.

Franki AS, Van Beneden K, Dewint P, Meeus I, Veys E, Deforce D, Elewaut D. 2005. Lymphotoxin $\alpha 1 \beta 2$ : A critical mediator in $\mathrm{V} \alpha 14 \mathrm{i}$ NKT cell differentiation. Mol Immunol 42: 413-417.

Franzoso G, Carlson L, Poljak L, Shores EW, Epstein S, Leonardi A, Grinberg A, Tran T, Scharton-Kersten T, Anver $\mathrm{M}$, et al. 1998. Mice deficient in nuclear factor (NF)-к $\mathrm{B} / \mathrm{p} 52$ present with defects in humoral responses, germinal center reactions, and splenic microarchitecture. J Exp Med 187: 147-159.

Franzoso G, Carlson L, Scharton-Kersten T, Shores EW, Epstein S, Grinberg A, Tran T, Shacter E, Leonardi A, Anver $\mathrm{M}$, et al. 1997a. Critical roles for the Bcl-3 oncoprotein in T cell-mediated immunity, splenic microarchitecture, and germinal center reactions. Immunity 6: 479-490.

Franzoso G, Carlson L, Xing L, Poljak L, Shores EW, Brown KD, Leonardi A, Tran T, Boyce BF, Siebenlist U. 1997b. Requirement for NF-кB in osteoclast and B-cell development. Genes Dev 11: 3482-3496.

Gerondakis S, Strasser A. 2003. The role of Rel/NF-кB transcription factors in B lymphocyte survival. Semin Immunol 15: 159-166.

Gerondakis S, Grumont RJ, Banerjee A. 2007. Regulating $\mathrm{B}$-cell activation and survival in response to TLR signals. Immunol Cell Biol 85: 471-475.

Gerondakis S, Grumont R, Rourke I, Grossmann M. 1998. The regulation and roles of Rel/NF- $\kappa$ B transcription factors during lymphocyte activation. Curr Opin Immunol 10: 353-359.

Gerondakis S, Grumont R, Gugasyan R, Wong L, Isomura I, Ho W, Banerjee A. 2006. Unravelling the complexities of the NF- $\kappa \mathrm{B}$ signalling pathway using mouse knockout and transgenic models. Oncogene 25: 6781-6799.

Ghosh S, Hayden MS. 2008. New regulators of NF-кB in inflammation. Nat Rev Immunol 8: 837-848.

Gilmore TD, Kalaitzidis D, Liang MC, Starczynowski DT. 2004. The c-Rel transcription factor and B-cell proliferation: A deal with the devil. Oncogene 23: 2275-2286.

Goldmit M, Ji Y, Skok J, Roldan E, Jung S, Cedar H, Bergman Y. 2005. Epigenetic ontogeny of the Igk locus during B cell development. Nat Immunol 6: 198-203.

Greve B, Weissert R, Hamdi N, Bettelli E, Sobel RA, Coyle A, Kuchroo VK, Rajewsky K, Schmidt-Supprian M. 2007. I $\kappa \mathrm{B}$ kinase $2 / \beta$ deficiency controls expansion of autoreactive $\mathrm{T}$ cells and suppresses experimental autoimmune encephalomyelitis. J Immunol 179: 179-185.

Grigoriadis G, Zhan Y, Grumont RJ, Metcalf D, Handman E, Cheers C, Gerondakis S. 1996. The Rel subunit of NF-кB-like transcription factors is a positive and negative regulator of macrophage gene expression: Distinct roles for Rel in different macrophage populations. EMBO J 15: 7099-7107.

Grossmann M, O’Reilly LA, Gugasyan R, Strasser A, Adams JM, Gerondakis S. 2000. The anti-apoptotic activities of Rel and RelA required during B-cell maturation involve the regulation of $\mathrm{Bcl}-2$ expression. EMBO J 19: 6351-6360.

Grumont RJ, Gerondakis S. 1990. Murine c-rel transcription is rapidly induced in T-cells and fibroblasts by mitogenic agents and the phorbol ester 12-O-tetradecanoylphorbol-13-acetate. Cell Growth Differ 1: 345-350.

Grumont RJ, Gerondakis S. 1994. The subunit composition of NF- $\kappa$ B complexes changes during B-cell development. Cell Growth Differ 5: 1321-1331.

Grumont RJ, Gerondakis S. 2000. Rel induces interferon regulatory factor 4 (IRF-4) expression in lymphocytes: Modulation of interferon-regulated gene expression by rel/nuclear factor кB. J Exp Med 191: 1281-1292.

Grumont RJ, Rourke IJ, Gerondakis S. 1999. Rel-dependent induction of A1 transcription is required to protect B cells from antigen receptor ligation-induced apoptosis. Genes Dev 13: 400-411.

Grumont R, Hochrein H, O’Keeffe M, Gugasyan R, White C, Caminschi I, Cook W, Gerondakis S. 2001. c-Rel regulates interleukin 12 p70 expression in CD8 $(+)$ dendritic cells by specifically inducing p35 gene transcription. J Exp Med 194: 1021-1032.

Grumont R, Lock P, Mollinari M, Shannon FM, Moore A, Gerondakis S. 2004. The mitogen-induced increase in $\mathrm{T}$ cell size involves $\mathrm{PKC}$ and NFAT activation of Rel/NF-кB-dependent c-myc expression. Immunity 21: 19-30.

Grumont RJ, Rourke IJ, O’Reilly LA, Strasser A, Miyake K, Sha W, Gerondakis S. 1998. B lymphocytes differentially use the Rel and nuclear factor $\kappa \mathrm{B} 1$ (NF-кB1) transcription factors to regulate cell cycle progression and apoptosis in quiescent and mitogen-activated cells. J Exp Med 187: $663-674$.

Grumont RJ, Strasser A, Gerondakis S. 2002. B cell growth is controlled by phosphatidylinosotol 3-kinase-dependent induction of Rel/NF- $\mathrm{B}$ regulated c-myc transcription. Mol Cell 10: 1283-1294.

Guo F, Weih D, Meier E, Weih F. 2007. Constitutive alternative NF- $\mathrm{B}$ signaling promotes marginal zone B-cell development but disrupts the marginal sinus and induces HEV-like structures in the spleen. Blood 110: 2381-2389.

Hardy RR, Kincade PW, Dorshkind K. 2007. The protean nature of cells in the B lymphocyte lineage. Immunity 26: $703-714$.

Harling-McNabb L, Deliyannis G, Jackson DC, Gerondakis S, Grigoriadis G, Brown LE. 2009. Mice lacking the transcription factor subunit Rel can clear an influenza infection and have functional anti-viral cytotoxic $\mathrm{T}$ cells but do not develop an optimal antibody response. Int Immunol 11: 1431-1439.

Hayden MS, Ghosh S. 2008. Shared principles in NF-кB signaling. Cell 132: 344-362.

Hayden MS, West AP, Ghosh S. 2006. NF-кB and the immune response. Oncogene 25: 6758-6780. 
Hehlgans T, Pfeffer K. 2005. The intriguing biology of the tumour necrosis factor/tumour necrosis factor receptor superfamily: Players, rules and the games. Immunology 115: $1-20$

Hettmann T, Leiden JM. 2000. NF- $\kappa$ B is required for the positive selection of $\mathrm{CD} 8+$ thymocytes. I Immunol 165: 5004-5010.

Hettmann T, DiDonato J, Karin M, Leiden JM. 1999. An essential role for nuclear factor $\kappa \mathrm{B}$ in promoting double positive thymocyte apoptosis. J Exp Med 189: 145-158.

Hikosaka Y, Nitta T, Ohigashi I, Yano K, Ishimaru N, Hayashi Y, Matsumoto M, Matsuo K, Penninger JM, Takayanagi $\mathrm{H}$, et al. 2008. The cytokine RANKL produced by positively selected thymocytes fosters medullary thymic epithelial cells that express autoimmune regulator. $I m$ munity 29: 438-450.

Hong JW, Hendrix DA, Papatsenko D, Levine MS. 2008. How the Dorsal gradient works: Insights from postgenome technologies. Proc Natl Acad Sci 105: 2007220076.

Humbert PO, Verona R, Trimarchi JM, Rogers C, Dandapani S, Lees JA. 2000. E2f3 is critical for normal cellular proliferation. Genes Dev 14: 690-703.

Igarashi H, Baba Y, Nagai Y, Jimi E, Ghosh S, Kincade PW. 2006. NF-кB is dispensable for normal lymphocyte development in bone marrow but required for protection of progenitors from TNF $\alpha$. Int Immunol 18: 653-659.

Inlay MA, Tian H, Lin T, Xu Y. 2004. Important roles for E protein binding sites within the immunoglobulin $\kappa$ chain intronic enhancer in activating $\mathrm{VK} \mathrm{J \kappa}$ rearrangement. $J$ Exp Med 200: 1205-2011.

Inoue J, Gohda J, Akiyama T. 2007. Characteristics and biological functions of TRAF6. Adv Exp Med Biol 597: $72-79$.

Irla M, Hugues S, Gill J, Nitta T, Hikosaka Y, Williams IR, Hubert FX, Scott HS, Takahama Y, Holländer GA, et al. 2008. Autoantigen-specific interactions with CD4+ thymocytes control mature medullary thymic epithelial cell cellularity. Immunity 29: 451-463.

Jensen KD, Chien YH. 2009. Thymic maturation determines $\gamma \delta \mathrm{T}$ cell function, but not their antigen specificities. Curr Opin Immunol 21: 140-145.

Jimi E, Phillips RJ, Rincon M, Voll R, Karasuyama H, Flavell R, Ghosh S. 2005. Activation of NF- $\kappa$ B promotes the transition of large, CD43+ pre-B cells to small, CD43pre-B cells. Int Immunol 17: 815-825.

Jimi E, Strickland I, Voll RE, Long M, Ghosh S. 2008. Differential role of the transcription factor NF- $\kappa \mathrm{B}$ in selection and survival of CD4+ and CD8+ thymocytes. Immunity 29: $523-537$.

Jin W, Reiley WR, Lee AJ, Wright A, Wu X, Zhang M, Sun SC. 2007. Deubiquitinating enzyme CYLD regulates the peripheral development and naive phenotype maintenance of B cells. J Biol Chem 282: 15884-15893.

Jones RG, Saibil SD, Pun JM, Elford AR, Bonnard M, Pellegrini M, Arya S, Parsons ME, Krawczyk CM, Gerondakis $\mathrm{S}$, et al. 2005. NF- $\mathrm{KB}$ couples protein kinase B/Akt signaling to distinct survival pathways and the regulation of lymphocyte homeostasis in vivo. J Immunol 175: 3790-3799.
Jost PJ, Weiss S, Ferch U, Gross O, Mak TW, Peschel C, Ruland J. 2007. Bcl10/Malt1 signaling is essential for TCR-induced NF- $\mathrm{kB}$ activation in thymocytes but dispensable for positive or negative selection. J Immunol 178: $953-960$.

Kaisho T, Takeda K, Tsujimura T, Kawai T, Nomura F, Terada N, Akira S. 2001. IкB kinase $\alpha$ is essential for mature B cell development and function. J Exp Med 193: $417-426$.

Kajiura F, Sun S, Nomura T, Izumi K, Ueno T, Bando Y, Kuroda N, Han H, Li Y, Matsushima A, et al. 2004. NF-K B-inducing kinase establishes self-tolerance in a thymic stroma-dependent manner. J Immunol 172: 2067-2075.

Kanno T, Franzoso G, Siebenlist U. 1994. Human T-cell leukemia virus type I Tax-protein-mediated activation of NF-к B from p100 (NF-к B2)-inhibited cytoplasmic reservoirs. Proc Natl Acad Sci 91: 12634-12638.

Kenter AL, Wuerffel R, Dominguez C, Shanmugam A, Zhang H. 2004. Mapping of a functional recombination motif that defines isotype specificity for $\mu \rightarrow \gamma 3$ switch recombination implicates NF- $\mathrm{\kappa B}$ p50 as the isotypespecific switching factor. J Exp Med 199: 617-627.

Kim MY, Kim KS, McConnell F, Lane P. 2009. Lymphoid tissue inducer cells: Architects of CD4 immune responses in mice and men. Clin Exp Immunol 157: 20-26.

Kingeter LM, Schaefer BC. 2008. Loss of protein kinase C $\theta$ Bcl10, or Malt1 selectively impairs proliferation and NF- $\kappa$ B activation in the CD4+ T cell subset. J Immunol 181: 6244-6254.

Kinoshita D, Hirota F, Kaisho T, Kasai M, Izumi K, Bando Y, Mouri Y, Matsushima A, Niki S, Han H, et al. 2006. Essential role of IкB kinase $\alpha$ in thymic organogenesis required for the establishment of self-tolerance. J Immunol 176: 3995-4002.

Kobayashi T, Kim TS, Jacob A, Walsh MC, Kadono Y, Fuentes-Pananá E, Yoshioka T, Yoshimura A, Yamamoto M, Kaisho T, et al. 2009. TRAF6 is required for generation of the B-1a B cell compartment as well as T celldependent and -independent humoral immune responses. PLoS One 4: e4736.

Koble C, Kyewski B. 2009. The thymic medulla: A unique microenvironment for intercellular self-antigen transfer J Exp Med 206: 1505-1513.

Köntgen F, Grumont RJ, Strasser A, Metcalf D, Li R, Tarlinton D, Gerondakis S. 1995. Mice lacking the c-rel protooncogene exhibit defects in lymphocyte proliferation, humoral immunity, and interleukin-2 expression. Genes Dev 9: 1965-1977.

Krieg AM. 2002. CpG motifs in bacterial DNA and their immune effects. Annu Rev Immunol 20: 709-760.

Kyewski B, Klein L. 2006. A central role for central tolerance. Annu Rev Immunol 24: 571-606.

Laurence A, O'Shea JJ. 2007. T(H)-17 differentiation: of mice and men. Nat Immunol 8: 903-905.

Laurencikiene J, Deveikaite V, Severinson E. 2001. HS1,2 enhancer regulation of germline $\epsilon$ and $\gamma 2 \mathrm{~b}$ promoters in murine B lymphocytes: Evidence for specific promoterenhancer interactions. J Immunol 167: 3257-3265.

Lee H, Arsura M, Wu M, Duyao M, Buckler AJ, Sonenshein GE. 1995. Role of Rel-related factors in control of c-myc gene transcription in receptor-mediated apoptosis 
of the murine B cell WEHI 231 line. J Exp Med 181: $1169-1177$.

Lee HH, Dadgostar H, Cheng Q, Shu J, Cheng G. 1999. NF-kB-mediated up-regulation of Bcl-x and Bfl-1/Al is required for $\mathrm{CD} 40$ survival signaling in $\mathrm{B}$ lymphocytes. Proc Natl Acad Sci 96: 9136-9141.

Levens D. 2002. Disentangling the MYC web. Proc Natl Acad Sci 99: 5757-5759.

Lin X, Wang D. 2004. The roles of CARMA1, Bcl10, and MALT1 in antigen receptor signaling. Semin Immunol 16: $429-435$.

Lindsley RC, Thomas M, Srivastava B, Allman D. 2007. Generation of peripheral B cells occurs via two spatially and temporally distinct pathways. Blood 109: 2521-2528.

Liston A, Rudensky AY. 2007. Thymic development and peripheral homeostasis of regulatory T cells. Curr Opin Immunol 19: 176-185.

Liu HH, Xie M, Schneider MD, Chen ZJ. 2006. Essential role of TAK1 in thymocyte development and activation. Proc Natl Acad Sci 103: 11677-11682.

Lopes-Carvalho T, Foote J, Kearney JF. 2005. Marginal zone B cells in lymphocyte activation and regulation. Curr Opin Immunol 17: 244-250.

Lu LF, Rudensky A. 2009. Molecular orchestration of differentiation and function of regulatory T cells. Genes Dev 23: $1270-1282$.

MacDonald HR, Mycko MP. 2007. Development and selection of V $\alpha$ 14i NKT cells. Curr Top Microbiol Immunol 314: $195-212$.

Mackay F, Schneider P. 2009. Cracking the BAFF code. Nat Rev Immunol 9: 491-502.

Makris C, Godfrey VL, Krähn-Senftleben G, Takahashi T, Roberts JL, Schwarz T, Feng L, Johnson RS, Karin M, 2000. Female mice heterozygous for IKK $\gamma /$ NEMO deficiencies develop a dermatopathy similar to the human Xlinked disorder incontinentia pigmenti. Mol Cell 5: 969-679.

Mandal M, Borowski C, Palomero T, Ferrando AA, Oberdoerffer P, Meng F, Ruiz-Vela A, Ciofani M, Zuniga-Pflucker JC, Screpanti I, et al. 2005. The BCL2A1 gene as a pre-T cell receptor-induced regulator of thymocyte survival. J Exp Med 201: 603-614.

Manis JP, Tian M, Alt FW. 2002. Mechanism and control of class-switch recombination. Trends Immunol 23: 31-39.

Martins VC, Boehm T, Bleul CC. 2008. Lt $\beta r$ signaling does not regulate Aire-dependent transcripts in medullary thymic epithelial cells. J Immunol 181: 400-407

Mason NJ, Liou HC, Hunter CA. 2004. T cell-intrinsic expression of c-Rel regulates Th1 cell responses essential for resistance to Toxoplasma gondii. J Immunol 172: 3704-3711.

Mathis D, Benoist C. 2009. Aire. Annu Rev Immunol 27: 287-312.

Matsushima A, Kaisho T, Rennert PD, Nakano H, Kurosawa K, Uchida D, Takeda K, Akira S, Matsumoto M. 2001. Essential role of nuclear factor (NF)- $\mathrm{kB}$-inducing kinase and inhibitor of $\kappa \mathrm{B}$ (ІкB) kinase $\alpha$ in NF- $\kappa \mathrm{B}$ activation through lymphotoxin $\beta$ receptor, but not through tumor necrosis factor receptor I. J Exp Med 193: 631-636.

McHeyzer-Williams MG. 2003. B cells as effectors. Curr Opin Immunol 15: 354-361.
McHeyzer-Williams LJ, McHeyzer-Williams MG. 2005. Antigen-specific memory B cell development. Annu Rev Immunol 23: 487-513.

Medoff BD, Sandall BP, Landry A, Nagahama K, Mizoguchi A, Luster AD, Xavier RJ. 2009. Differential requirement for CARMA1 in agonist-selected T-cell development. Eur J Immunol 39: 78-84.

Mineva ND, Rothstein TL, Meyers JA, Lerner A, Sonenshein GE. 2007. CD40 ligand-mediated activation of the de novo RelB NF- $\mathrm{kB}$ synthesis pathway in transformed B cells promotes rescue from apoptosis. J Biol Chem 282: $17475-17485$.

Mise-Omata S, Kuroda E, Niikura J, Yamashita U, Obata Y, Doi TS. 2007. A proximal $\kappa B$ site in the IL-23 p19 promoter is responsible for RelA- and c-Rel-dependent transcription. J Immunol 179: 6596-6603.

Mittrücker HW, Matsuyama T, Grossman A, Kündig TM, Potter J, Shahinian A, Wakeham A, Patterson B, Ohashi PS, Mak TW. 1997. Requirement for the transcription factor LSIRF/IRF4 for mature B and T lymphocyte function. Science 275: 540-543.

Molinero LL, Yang J, Gajewski T, Abraham C, Farrar MA, Alegre ML. 2009. CARMA1 controls an early checkpoint in the thymic development of FoxP3 + regulatory T cells. J Immunol 182: 6736-6743.

Molitor JA, Walker WH, Doerre S, Ballard DW, Greene WC. 1990. NF-к B: A family of inducible and differentially expressed enhancer-binding proteins in human T cells. Proc Natl Acad Sci 87: 10028-10032.

Mora AL, Stanley S, Armistead W, Chan AC, Boothby M. 2001. Inefficient ZAP-70 phosphorylation and decreased thymic selection in vivo result from inhibition of NF- $\kappa \mathrm{B} /$ Rel. J Immunol 167: 5628-5635.

Moran ST, Cariappa A, Liu H, Muir B, Sgroi D, Boboila C, Pillai S. 2007. Synergism between NF- $\mathrm{K} 1 / \mathrm{p} 50$ and Notch2 during the development of marginal zone B lymphocytes. J Immunol 179: 195-200.

Moriyama H, Yonehara S. 2007. Rapid up-regulation of c-FLIP expression by BCR signaling through the PI3K/ Akt pathway inhibits simultaneously induced Fasmediated apoptosis in murine B lymphocytes. Immunol Lett 109: 36-46.

Morley SC, Weber KS, Kao H, Allen PM. 2008. Protein kinase $\mathrm{C}-\theta$ is required for efficient positive selection. J Immunol 181: 4696-4708.

Mueller SN, Ahmed R. 2008. Lymphoid stroma in the initiation and control of immune responses. Immunol Rev 2008 224: 284-294.

Müller JR, Siebenlist U. 2003. Lymphotoxin $\beta$ receptor induces sequential activation of distinct NF- $\mathrm{B}$ B factors via separate signaling pathways. J Biol Chem 278: 12006-12012.

Nemazee D. 2006. Receptor editing in lymphocyte development and central tolerance. Nat Rev Immunol 6: $728-740$.

Nitta T, Murata S, Ueno T, Tanaka K, Takahama Y. 2008. Thymic microenvironments for T-cell repertoire formation. Adv Immunol 99: 59-94.

Northrup DL, Allman D. 2008. Transcriptional regulation of early B cell development. Immunol Res 42: 106-117. 
O'Keeffe M, Grumont RJ, Hochrein H, Fuchsberger M, Gugasyan R, Vremec D, Shortman K, Gerondakis S. 2005. Distinct roles for the NF- $\mathrm{kB} 1$ and c-Rel transcription factors in the differentiation and survival of plasmacytoid and conventional dendritic cells activated by TLR- 9 signals. Blood 106: 3457-3464.

Otipoby KL, Sasaki Y, Schmidt-Supprian M, Patke A, Gareus R, Pasparakis M, Tarakhovsky A, Rajewsky K. 2008. BAFF activates Akt and Erk through BAFF-R in an IKK1dependent manner in primary mouse B cells. Proc Natl Acad Sci 105: 12435-12438.

Ouaaz F, Arron J, Zheng Y, Choi Y, Beg AA. 2002. Dendritic cell development and survival require distinct NF- $\mathrm{B}$ subunits. Immunity 16: 257-270.

Owyang AM, Tumang JR, Schram BR, Hsia CY, Behrens TW, Rothstein TL, Liou HC. 2001. c-Rel is required for the protection of $\mathrm{B}$ cells from antigen receptormediated, but not Fas-mediated, apoptosis. J Immunol 167: $4948-4956$

Palmer S, Chen YH. 2008. Bcl-3, a multifaceted modulator of NF-кB-mediated gene transcription. Immunol Res 42: $210-218$.

Pappu BP, Lin X. 2006. Potential role of CARMAl in CD40-induced splenic B cell proliferation and marginal zone B cell maturation. Eur J Immunol 36: 3033-3043.

Pasparakis M, Schmidt-Supprian M, Rajewsky K. 2002. IкB kinase signaling is essential for maintenance of mature B cells. J Exp Med 196: 743-752.

Paxian S, Merkle H, Riemann M, Wilda M, Adler G, Hameister H, Liptay S, Pfeffer K, Schmid RM. 2002. Abnormal organogenesis of Peyer's patches in mice deficient for

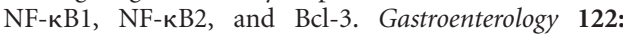
1853-1868.

Pohl T, Gugasyan R, Grumont RJ, Strasser A, Metcalf D, Tarlinton D, Sha W, Baltimore D, Gerondakis S. 2002. The combined absence of NF- $\kappa$ B1 and c-Rel reveals that overlapping roles for these transcription factors in the $\mathrm{B}$ cell lineage are restricted to the activation and function of mature cells. Proc Natl Acad Sci 99: 4514-4519.

Poljak L, Carlson L, Cunningham K, Kosco-Vilbois MH, Siebenlist U. 1999. Distinct activities of p52/NF-к B required for proper secondary lymphoid organ microarchitecture: Functions enhanced by Bcl-3. J Immunol 163: 6581-6588.

Poovassery JS, Vanden Bush TJ, Bishop GA. 2009. Antigen receptor signals rescue B cells from TLR tolerance. J Immunol 183: 2974-2983.

Qin J, Konno H, Ohshima D, Yanai H, Motegi H, Shimo Y, Hirota F, Matsumoto M, Takaki S, Inoue J, et al. 2007. Developmental stage-dependent collaboration between the TNF receptor-associated factor 6 and lymphotoxin pathways for B cell follicle organization in secondary lymphoid organs. J Immunol 179: 6799-6807.

Randall TD, Carragher DM, Rangel-Moreno J. 2008. Development of secondary lymphoid organs. Annu Rev Immunol 26: 627-650

Rao S, Gerondakis S, Woltring D, Shannon MF. 2003. c-Rel is required for chromatin remodeling across the IL-2 gene promoter. J Immunol 170: 3724-3731.

Rauch M, Tussiwand R, Bosco N, Rolink AG. 2009. Crucial role for BAFF-BAFF-R signaling in the survival and maintenance of mature B cells. PLoS One 4: e5456.
Ren H, Schmalstieg A, van Oers NS, Gaynor RB. 2002. I-к B kinases $\alpha$ and $\beta$ have distinct roles in regulating murine T cell function. J Immunol 168: 3721-3731.

Ribot JC, deBarros A, Pang DJ, Neves JF, Peperzak V, Roberts SJ, Girardi M, Borst J, Hayday AC, Pennington DJ, et al. 2009. CD27 is a thymic determinant of the balance between interferon- $\gamma$ - and interleukin 17-producing $\gamma \delta \mathrm{T}$ cell subsets. Nat Immunol 10: 427-436.

Rothstein TL, Zhong X, Schram BR, Negm RS, Donohoe TJ, Cabral DS, Foote LC, Schneider TJ. 2000. Receptorspecific regulation of B-cell susceptibility to Fasmediated apoptosis and a novel Fas apoptosis inhibitory molecule. Immunol Rev 176: 116-133.

Ruddle NH, Akirav EM. 2009. Secondary lymphoid organs: Responding to genetic and environmental cues in ontogeny and the immune response. J Immunol 183: $2205-2212$.

Saibil SD, Jones RG, Deenick EK, Liadis N, Elford AR, Vainberg MG, Baerg H, Woodgett JR, Gerondakis S, Ohashi PS. 2007. CD4+ and CD8 + T cell survival is regulated differentially by protein kinase $\mathrm{C} \theta$, c-Rel, and protein kinase B. J Immunol 178: 2932-2939.

Sasaki Y, Calado DP, Derudder E, Zhang B, Shimizu Y, Mackay F, Nishikawa S, Rajewsky K, Schmidt-Supprian M. 2008. NIK overexpression amplifies, whereas ablation of its TRAF3-binding domain replaces BAFF:BAFFR-mediated survival signals in B cells. Proc Natl Acad Sci 105: 10883-10888.

Sasaki Y, Casola S, Kutok JL, Rajewsky K, Schmidt-Supprian M. 2004. TNF family member B cell-activating factor (BAFF) receptor-dependent and -independent roles for BAFF in B cell physiology. J Immunol 173: 2245-2252.

Sasaki Y, Derudder E, Hobeika E, Pelanda R, Reth M, Rajewsky K, Schmidt-Supprian M. 2006. Canonical NF-кB activity, dispensable for B cell development, replaces BAFF-receptor signals and promotes B cell proliferation upon activation. Immunity 24: 729-739.

Sasaki Y, Schmidt-Supprian M, Derudder E, Rajewsky K. 2007. Role of NFKB signaling in normal and malignant B cell development. Adv Exp Med Biol 596: 149-154.

Sato S, Sanjo H, Takeda K, Ninomiya-Tsuji J, Yamamoto M, Kawai T, Matsumoto K, Takeuchi O, Akira S. 2005. Essential function for the kinase TAK1 in innate and adaptive immune responses. Nat Immunol 6: 1087-1095.

Sato S, Sanjo H, Tsujimura T, Ninomiya-Tsuji J, Yamamoto M, Kawai T, Takeuchi O, Akira S. 2006. TAK1 is indispensable for development of $\mathrm{T}$ cells and prevention of colitis by the generation of regulatory T cells. Int Immunol 18: 1405-1411.

Schauer SL, Bellas RE, Sonenshein GE. 1998. Dominant signals leading to inhibitor $\mathrm{\kappa B}$ protein degradation mediate CD40 ligand rescue of WEHI 231 immature B cells from receptor-mediated apoptosis. I Immunol 160: 4398-4405.

Schimpl A, Berberich I, Kneitz B, Krämer S, Santner-Nanan B, Wagner S, Wolf M, Hünig T. 2002. IL-2 and autoimmune disease. Cytokine Growth Factor Rev 13: 369-378.

Schmidt-Supprian M, Bloch W, Courtois G, Addicks K, Israël A, Rajewsky K, Pasparakis M. 2000. NEMO/IKK $\gamma$-deficient mice model incontinentia pigmenti. Mol Cell 5: 981-992. 
Schmidt-Supprian M, Courtois G, Tian J, Coyle AJ, Israël A, Rajewsky K, Pasparakis M. 2003. Mature T cells depend on signaling through the IKK complex. Immunity 19: 377-389.

Schmidt-Supprian M, Tian J, Grant EP, Pasparakis M, Maehr R, Ovaa H, Ploegh HL, Coyle AJ, Rajewsky K. 2004a. Differential dependence of CD4+CD25 + regulatory and natural killer-like $\mathrm{T}$ cells on signals leading to NF-кB activation. Proc Natl Acad Sci 101: 4566-4571.

Schmidt-Supprian M, Tian J, Ji H, Terhorst C, Bhan AK, Grant EP, Pasparakis M, Casola S, Coyle AJ, Rajewsky K. 2004b. I к B kinase 2 deficiency in T cells leads to defects in priming, B cell help, germinal center reactions, and homeostatic expansion. J Immunol 173: 1612-1619.

Schram BR, Tze LE, Ramsey LB, Liu J, Najera L, Vegoe AL, Hardy RR, Hippen KL, Farrar MA, Behrens TW. 2008. B cell receptor basal signaling regulates antigeninduced Ig light chain rearrangements. J Immunol 180: 4728-4741.

Schuman J, Chen Y, Podd A, Yu M, Liu HH, Wen R, Chen ZJ, Wang D. 2009. A critical role of TAK1 in B-cell receptormediated nuclear factor $\mathrm{\kappa B}$ activation. Blood 113: 4566-4574.

Seach N, Ueno T, Fletcher AL, Lowen T, Mattesich M, Engwerda CR, Scott HS, Ware CF, Chidgey AP, Gray DH, Boyd RL. 2008. The lymphotoxin pathway regulates Aire-independent expression of ectopic genes and chemokines in thymic stromal cells. J Immunol 180: 5384-5392.

Sen R. 2004. NF-кB and the immunoglobulin кgene enhancer. J Exp Med 200: 1099-1102.

Senftleben U, Cao Y, Xiao G, Greten FR, Krähn G, Bonizzi G, Chen Y, Hu Y, Fong A, Sun SC, Karin M. 2001a. Activation by IKK $\alpha$ of a second, evolutionary conserved, NF-K B signaling pathway. Science 293: 1495-1499.

Senftleben U, Li ZW, Baud V, Karin M. 2001b. IKK $\beta$ is essential for protecting T cells from TNF $\alpha$-induced apoptosis. Immunity 14: 217-230.

Sha WC, Liou HC, Tuomanen EI, Baltimore D. 1995 Targeted disruption of the p50 subunit of NF-к B leads to multifocal defects in immune responses. Cell 80: $321-330$.

Shaffer AL, Emre NC, Lamy L, Ngo VN, Wright G, Xiao W, Powell J, Dave S, Yu X, Zhao H, et al. 2008. IRF4 addiction in multiple myeloma. Nature 454: 226-231.

Shaffer AL, Rosenwald A, Hurt EM, Giltnane JM, Lam LT, Pickeral OK, Staudt LM. 2001. Signatures of the immune response. Immunity 15: 375-385.

Siebenlist U, Brown K, Claudio E. 2005. Control of lymphocyte development by nuclear factor-кB. Nat Rev Immuno 5: 435-445.

Sivakumar V, Hammond KJ, Howells N, Pfeffer K, Weih F. 2003. Differential requirement for Rel/nuclear factor $\kappa$ $\mathrm{B}$ family members in natural killer $\mathrm{T}$ cell development. J Exp Med 197: 1613-1621.

Song J, So T, Croft M. 2008. Activation of NF-кB1 by OX40 contributes to antigen-driven $\mathrm{T}$ cell expansion and survival. J Immunol 180: 7240-7248.

Sriskantharajah S, Belich MP, Papoutsopoulou S, Janzen J, Tybulewicz V, Seddon B, Ley SC. 2009. Proteolysis of
NF-кB1 p105 is essential for T cell antigen receptor-induced proliferation. Nat Immunol 10: 38-47.

Stadanlick JE, Cancro MP. 2008. BAFF and the plasticity of peripheral B cell tolerance. Curr Opin Immunol 20: $158-161$.

Stadanlick JE, Kaileh M, Karnell FG, Scholz JL, Miller JP, Quinn WJ, Brezski RJ 3rd, Treml LS, Jordan KA, Monroe JG, et al. 2008. Tonic B cell antigen receptor signals supply an NF-кB substrate for prosurvival BLyS signaling. Nat Immunol 9: 1379-1387.

Stanic AK, Bezbradica JS, Park JJ, Matsuki N, Mora AL, Van Kaer L, Boothby MR, Joyce S. 2004. NF-к B controls cell fate specification, survival, and molecular differentiation of immunoregulatory natural $\mathrm{T}$ lymphocytes. J Immunol 172: $2265-2273$

Stanic AK, Bezbradica JS, Park JJ, Van Kaer L, Boothby MR, Joyce S. 2004. Cutting edge: The ontogeny and function of Va14Ja18 natural $\mathrm{T}$ lymphocytes require signal processing by protein kinase $\mathrm{C} \theta$ and NF-к B. J Immunol 172: $4667-4671$.

Stocker H, Hafen E. 2000. Genetic control of cell size. Curr Opin Genet Dev 10: 529-535.

Strasser A, Jost PJ, Nagata S. 2009. The many roles of FAS receptor signaling in the immune system. Immunity 30: $180-192$.

Sun Z, Arendt CW, Ellmeier W, Schaeffer EM, Sunshine MJ, Gandhi L, Annes J, Petrzilka D, Kupfer A, Schwartzberg $\mathrm{PL}$, et al. 2000. PKC- $\theta$ is required for TCR-induced NF-кB activation in mature but not immature Tlymphocytes. Nature 404: 402-407.

Suto H, Katakai T, Sugai M, Kinashi T, Shimizu A. 2009. CXCL13 production by an established lymph node stromal cell line via lymphotoxin- $\beta$ receptor engagement involves the cooperation of multiple signaling pathways. Int Immunol 21: 467-476.

Taghon T, Rothenberg EV. 2008. Molecular mechanisms that control mouse and human TCR- $\alpha \beta$ and TCR- $\gamma \delta$ T cell development. Semin Immunopathol 30: 383-398.

Thedrez A, Sabourin C, Gertner J, Devilder MC, AllainMaillet S, Fournié JJ, Scotet E, Bonneville M. 2007. Self/non-self discrimination by human $\gamma \delta$ T cells: Simple solutions for a complex issue? Immunol Rev 215: $123-135$.

Thomas MD, Srivastava B, Allman D. 2006. Regulation of peripheral B cell maturation. Cell Immunol 239: 92-102.

Thome M. 2004. CARMA1, BCL-10 and MALT1 in lymphocyte development and activation. Nat Rev Immunol 4: 348-359.

Tucker E, O’Donnell K, Fuchsberger M, Hilton AA, Metcalf D, Greig K, Sims NA, Quinn JM, Alexander WS, Hilton DJ, et al. 2007. A novel mutation in the Nfkb2 gene generates an NF-к B2 "super repressor". J Immunol 179: 7514-7522.

Tykocinski LO, Sinemus A, Kyewski B. 2008. The thymus medulla slowly yields its secrets. Ann NY Acad Sci 1143: 105-122.

Vallabhapurapu S, Karin M. 2009. Regulation and function of NF- $\mathrm{BB}$ transcription factors in the immune system. Аппи Rev Immunol 27: 693-733. 
Venkataraman L, Burakoff SJ, Sen R. 1995. FK506 inhibits antigen receptor-mediated induction of c-rel in B and T lymphoid cells. J Exp Med 181: 1091-1099.

Venkataraman L, Wang W, Sen R. 1996. Differential regulation of c-Rel translocation in activated B and T cells. J Immunol 157: 1149-1155.

Vallabhapurapu S, Powolny-Budnicka I, Riemann M, Schmid RM, Paxian S, Pfeffer K, Körner H, Weih F. 2008. Rel/NF-кB family member RelA regulates NK1.1- to NK1.1+ transition as well as IL-15-induced expansion of NKT cells. Eur J Immunol 38: 3508-3519.

Verkoczy L, Aït-Azzouzene D, Skog P, Märtensson A, Lang J, Duong B, Nemazee D. 2005. A role for nuclear factor $\kappa$ B/ rel transcription factors in the regulation of the recombinase activator genes. Immunity 22: 519-531.

Voll RE, Jimi E, Phillips RJ, Barber DF, Rincon M, Hayday AC, Flavell RA, Ghosh S. 2000. NF-к B activation by the pre-T cell receptor serves as a selective survival signal in T lymphocyte development. Immunity 13: 677-689.

Vondenhoff MF, Kraal G, Mebius RE. 2007. Lymphoid organogenesis in brief. Eur J Immunol. 37 Suppl 1: S46-52.

Wan YY, DeGregori J. 2003. The survival of antigenstimulated $\mathrm{T}$ cells requires NFKB-mediated inhibition of p73 expression. Immunity 18: 331-342.

Wan YY, Chi H, Xie M, Schneider MD, Flavell RA. 2006. The kinase TAK1 integrates antigen and cytokine receptor signaling for T cell development, survival and function. Nat Immunol 7: 851-858.

Wang L, Wuerffel R, Kenter AL. 2006. NF-к B binds to the immunoglobulin $\mathrm{S} \gamma 3$ region in vivo during class switch recombination. Eur J Immunol 36: 3315-3323.

Wang J, Wang X, Hussain S, Zheng Y, Sanjabi S, Ouaaz F, Beg AA. 2007. Distinct roles of different NF-K B subunits in regulating inflammatory and $\mathrm{T}$ cell stimulatory gene $\mathrm{ex}$ pression in dendritic cells. J Immunol 178: 6777-6788.

Waterfield MR, Zhang M, Norman LP, Sun SC. 2003 NF- $\mathrm{B} 1 / \mathrm{p} 105$ regulates lipopolysaccharide-stimulated MAP kinase signaling by governing the stability and function of the Tpl2 kinase. Mol Cell 11: 685-694.

Weih F, Caamaño J. 2003. Regulation of secondary lymphoid organ development by the nuclear factor- $\mathrm{\kappa B}$ signal transduction pathway. Immunol Rev 195: 91-105.

Weih DS, Yilmaz ZB, Weih F. 2001. Essential role of RelB in germinal center and marginal zone formation and proper expression of homing chemokines. I Immunol 167: 1909-1919.

Weih F, Carrasco D, Durham SK, Barton DS, Rizzo CA, Ryseck RP, Lira SA, Bravo R. 1995. Multiorgan inflammation and hematopoietic abnormalities in mice with a targeted disruption of RelB, a member of the NF- $\kappa$ B/ Rel family. Cell 80: 331-340.

Weil R, Israël A. 2006. Deciphering the pathway from the TCR to NF-кB. Cell Death Differ 13: 826-833.
Wu L, Timmers C, Maiti B, Saavedra HI, Sang L, Chong GT, Nuckolls F, Giangrande P, Wright FA, Field SJ, et al. 2001. The E2F1-3 transcription factors are essential for cellular proliferation. Nature 414: 457-462.

Xiong N, Raulet DH. 2007. Development and selection of $\gamma \delta \mathrm{T}$ cells. Immunol Rev 215: 15-31.

Yamada T, Mitani T, Yorita K, Uchida D, Matsushima A, Iwamasa K, Fujita S, Matsumoto M. 2000. Abnormal immune function of hemopoietic cells from alymphoplasia (aly) mice, a natural strain with mutant NF-к B-inducing kinase. J Immunol 165: 804-812.

Yamamoto M, Takeda K. 2008. Role of nuclear IкB proteins in the regulation of host immune responses. J Infect Chemother 14: 265-269.

Yano M, Kuroda N, Han H, Meguro-Horike M, Nishikawa Y, Kiyonari H, Maemura K, Yanagawa Y, Obata K, Takahashi S, et al. 2008. Aire controls the differentiation program of thymic epithelial cells in the medulla for the establishment of self-tolerance. J Exp Med 205: 2827-2838.

Yilmaz ZB, Weih DS, Sivakumar V, Weih F. 2003. RelB is required for Peyer's patch development: Differential regulation of p52-RelB by lymphotoxin and TNF. EMBO J 22: $121-130$.

Yoshida H, Naito A, Inoue J, Satoh M, Santee-Cooper SM, Ware CF, Togawa A, Nishikawa S, Nishikawa S. 2002. Different cytokines induce surface lymphotoxin- $\alpha \beta$ on IL-7 receptor- $\alpha$ cells that differentially engender lymph nodes and Peyer's patches. Immunity 17: 823-833.

Zazzeroni F, Papa S, Algeciras-Schimnich A, Alvarez K, Melis T, Bubici C, Majewski N, Hay N, De Smaele E, Peter ME, et al. 2003. Gadd $45 \beta$ mediates the protective effects of CD40 costimulation against Fas-induced apoptosis. Blood 102: 3270-3279.

Zelazowski P, Shen Y, Snapper CM. 2000. NF-кB/p50 and $\mathrm{NF}-\kappa \mathrm{B} / \mathrm{c}-$ Rel differentially regulate the activity of the $3^{\prime} \alpha \mathrm{E}-\mathrm{hsl}, 2$ enhancer in normal murine B cells in an activation-dependent manner. Int Immunol 12: 1167-1172.

Zhan Y, Gerondakis S, Coghill E, Bourges D, Xu Y, Brady JL, Lew AM. 2008. Glucocorticoid-induced TNF receptor expression by $\mathrm{T}$ cells is reciprocally regulated by NF- $\kappa \mathrm{B}$ and NFAT. J Immunol 181: 5405-5413.

Zhang X, Wang H, Claudio E, Brown K, Siebenlist U. 2007. A role for the IкB family member Bcl-3 in the control of central immunologic tolerance. Immunity 27: 438-452.

Zheng Y, Vig M, Lyons J, Van Parijs L, Beg AA. 2003. Combined deficiency of p50 and cRel in CD4 $+\mathrm{T}$ cells reveals an essential requirement for nuclear factor $\mathrm{\kappa B}$ in regulating mature $\mathrm{T}$ cell survival and in vivo function. J Exp Med 197: 861-874.

Zhu M, Chin RK, Christiansen PA, Lo JC, Liu X, Ware C, Siebenlist U, Fu YX. 2006. NF-кB2 is required for the establishment of central tolerance through an Aire-dependent pathway. J Clin Invest 116: 2964-2971. 


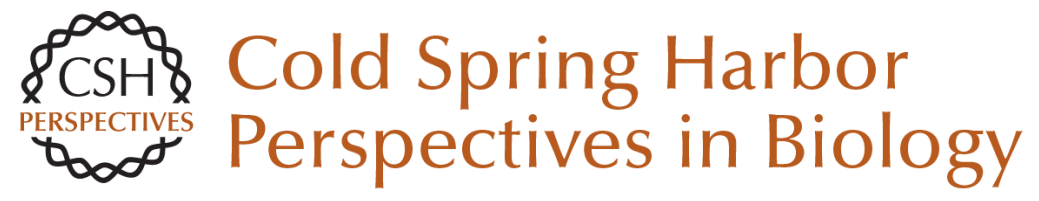

\section{Roles of the NF-kB Pathway in Lymphocyte Development and Function}

Steve Gerondakis and Ulrich Siebenlist

Cold Spring Harb Perspect Biol 2010; doi: 10.1101/cshperspect.a000182 originally published online December 23, 2009

\section{Subject Collection NF-kB}

Use of Forward Genetics to Discover Novel

Regulators of NF- $\mathrm{KB}$ Tao Lu and George R. Stark

Selectivity of the NF-kB Response Ranjan Sen and Stephen T. Smale

NF- $\kappa B$ in the Nervous System Barbara Kaltschmidt and Christian Kaltschmidt

Signaling to NF- $\kappa B$ : Regulation by Ubiquitination Ingrid E. Wertz and Vishva M. Dixit

Ubiquitination and Degradation of the Inhibitors of NF- $\kappa B$

Naama Kanarek, Nir London, Ora Schueler-Furman, et al.

A Structural Guide to Proteins of the NF- $\mathrm{KB}$ Signaling Module

Tom Huxford and Gourisankar Ghosh

NF-kB in the Immune Response of Drosophila Charles Hetru and Jules A. Hoffmann

\section{Control of NF-kB-dependent Transcriptional}

Responses by Chromatin Organization Gioacchino Natoli
Oncogenic Activation of NF- $\mathrm{kB}$

Louis M. Staudt

The Regulatory Logic of the NF- $\mathrm{kB}$ Signaling

System Ellen O'Dea and Alexander Hoffmann

Roles of the NF- $k B$ Pathway in Lymphocyte

Development and Function

Steve Gerondakis and Ulrich Siebenlist

The IKK Complex, a Central Regulator of NF- $\mathrm{KB}$

Activation Alain Israël

NF- $\kappa B$ in the Nervous System

Barbara Kaltschmidt and Christian Kaltschmidt

The Nuclear Factor NF- $\kappa B$ Pathway in Inflammation

Toby Lawrence

NF- $k B$ as a Critical Link Between Inflammation and Cancer Michael Karin

Specification of DNA Binding Activity of NF-KB Proteins

Fengyi Wan and Michael J. Lenardo

For additional articles in this collection, see http://cshperspectives.cshlp.org/cgi/collection/

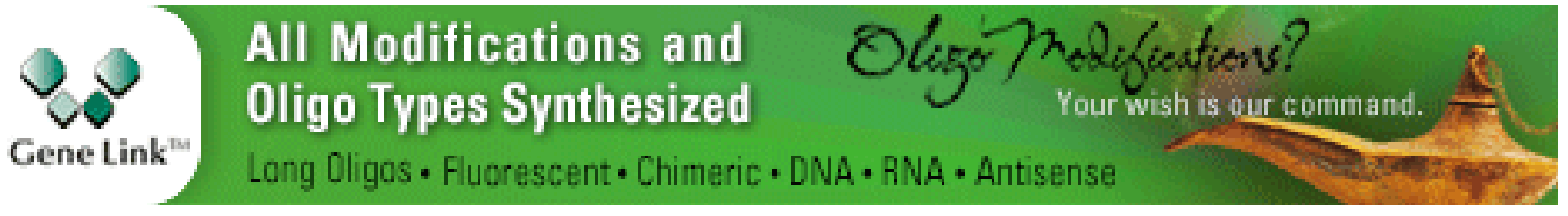

Copyright @ 2010 Cold Spring Harbor Laboratory Press; all rights reserved 